\title{
Stratigraphic and Structural Framework of Upper Middle Ordovician Rocks in the Head Lake-Burleigh Falls Area of South-Central Ontario \\ Cadre stratigraphique et structural des roches de l'Ordovicien moyen supérieur dans la région de Head Lake-Burleigh Falls, au centre-sud de l'Ontario Stratigraphischer und struktureller Rahmen der Felsen aus
dem oberen mittleren Ordovizium in der Gegend von Head
Lake-Burleigh Falls im südlichen Zentrum von Ontario
}

Bruce V. Sanford

Volume 47, numéro 3, 1993

La néotectonique de la région des Grands Lacs

Neotectonics of the Great Lakes area

URI : https://id.erudit.org/iderudit/032956ar

DOI : https://doi.org/10.7202/032956ar

Aller au sommaire du numéro

\section{Éditeur(s)}

Les Presses de l'Université de Montréal

\section{ISSN}

0705-7199 (imprimé)

1492-143X (numérique)

Découvrir la revue

\section{Citer cet article}

Sanford, B. V. (1993). Stratigraphic and Structural Framework of Upper Middle Ordovician Rocks in the Head Lake-Burleigh Falls Area of South-Central Ontario. Géographie physique et Quaternaire, 47(3), 253-268.

https://doi.org/10.7202/032956ar

\section{Résumé de l'article}

Des levés de terrain faits dans la région de Head Lake-Burleigh Falls, portant surtout sur les formations de Covey HiII (?), Shadow Lake, Gull River et Coboconk ont fait ressortir la présence de failles. Les déformations tectoniques observées et supposés, ainsi que les changements de faciès dans le Shadow Lake et le cours inférieur de la GuII River, montrent qu'il y a eu une succession de mouvements du socle pendant le Phanérozoïque. Ces mouvements se sont produits de l'Hadryanien-Cambrien inférieur à l'Ordovicien moyen, puis jusqu'après l'Ordovicien moyen supérieur. Certains des premiers mouvements (Hadryanien-Cambrien inférieur à l'Ordovicien moyen) semblent coïncider avec la tectonique des plaques, et y être reliés, et avec l'orogenèse du Taconique qui s'est manifestée sur les marges sud-ouest du continent nord-américain. La formation de failles dans les blocs après l'Ordovicien moyen, d'autre part, a pu être provoquée par un ou plusieurs événements épirogénétiques liés aux orogenèses du dernier étage du Taconique, de l'Acadien et de l'Alléghanien de l'Ordovicien supérieur au Carbonifère pendant la formation des fossés d'effondrement lié à la séparation des continents et le début de l'expansion océanique au Mésozoïque inférieur. 


\section{STRATIGRAPHIC AND STRUCTURAL FRAMEWORK OF UPPER MIDDLE ORDOVICIAN ROCKS IN THE HEAD LAKE- BURLEIGH FALLS AREA OF SOUTH- CENTRAL ONTARIO}

Bruce V. SANFORD, Independent Exploration Geologist,17 Meadowglade Gardens, Nepean, Ontario K2G 5J4.

ABSTRACT Field investigations in the Head Lake-Burleigh Falls area of southcentral Ontario, that focused mainly on the Covey Hill(?), Shadow Lake, Gull River and Coboconk formations along the Paleozoic escarpment, provided clear evidence of faulting. Observed and inferred structural deformation, coupled with facies changes within the Shadow Lake and lower Gull River, point to a succession of basement movements during the Phanerozoic. These range from Hadrynian-Early Cambrian, through Middle Ordovician to post-late Middle Ordovician times. Some of the earlier movements (Hadrynian-Early Cambrian to late Middle Ordovician) appear to be coincident with, and probably related to, plate tectonic events and the associated Taconian orogeny that were in progress along the southeastern margins of the North American continent. Post-Middle Ordovician block faulting, on the other hand, may have been triggered by any number of epeirogenic events related to late stage Taconian, Acadian or Alleghanian orogenies in Late Ordovician to Carboniferous times, or possibly to rifting associated with continental break-up and initiation of seafloor spreading processes in the early Mesozoic.
RÉSUMÉ Cadre stratigraphique et structural des roches de l'Ordovicien moyen supérieur dans la région de Head Lake-Burleigh Falls, au centre-sud de l'Ontario. Des levés de terrain faits dans la région de Head LakeBurleigh Falls, portant surtout sur les formations de Covey Hill (?), Shadow Lake, Gull River et Coboconk ont fait ressortir la présence de failles. Les déformations tectoniques observées et supposés, ainsi que les changements de faciès dans le Shadow Lake et le cours inférieur de la Gull River, montrent qu'il y a eu une succession de mouvements du socle pendant le Phanérozoïque. Ces mouvements se sont produits de l'Hadryanien-Cambrien inférieur à l'Ordovicien moyen, puis jusqu'après l'Ordovicien moyen supérieur. Certains des premiers mouvements (Hadryanien- Cambrien inférieur à l'Ordovicien moyen) semblent coïncider avec la tectonique des plaques, et $y$ être reliés, et avec l'orogénèse du Taconique qui s'est manifestée sur les marges sud-ouest du continent nordaméricain. La formation de failles dans les blocs après l'Ordovicien moyen, d'autre part, a pu être provoquée par un ou plusieurs événements épirogénétiques liés aux orogénèses du dernier étage du Taconique, de l'Acadien et de l'Alléghanien de l'Ordovicien supérieur au Carbonifère pendant la formation des fossés d'effondrement lié à la séparation des continents et le début de l'expansion océanique au Mésozoïque inférieur.
ZUSAMMENFASSUNG Stratigraphischer und struktureller Rahmen der Felsen aus dem oberen mittleren Ordovizium in der Gegend von Head Lake-Burleigh Falls im südlichen Zentrum von Ontario. Feldforschungen im Head Lake-Burleigh FallsGebiet, südliches Zentrum von Ontario, die sich haupt-sächlich auf die Bildungen von Covey Hill(?), Shadow Lake, Gull River und Coboconk entlang des paläozoischen Steilabfalls konzentrierten, ergaben ein klares Bild der Verwerfung. Die beobachteten und vermuteten strukturellen Verformungen weisen zusammen mit Fazies-Änderungen im Shadow Lake und dem unteren Lauf des Gull River auf eine Aufeinander-folge von Untergrundbewegungen während des Phanerozoikums. Diese reichen vom frühhadrynischen Kambrium durch das mittlere Ordovizium bis zu Zeiten nach dem späten mittleren Ordovizium. Einige der früheren Bewegungen (früh-hadrynisches Kambrium bis spätes mittleres Ordovizium) scheinen mit der Tektonik der Platten sowie der takonischen Orogenese, welche entlang der südöstlichen Rander des nordamerikanischen Kontinents stattgefunden haben, zeitlich zusammenzufallen und verbunden zu sein. Die Bildung von Brüchen in den Blöcken nach dem mittleren Ordovizium könnte andererseits durch ein oder mehrere epirogenetische Ereignisse ausgelöst worden sein, verbunden mit den Orogenesen der letzten takonischen, akadischen und alleghanischen Stufe vom späten Ordovizium bis zum Karbon, oder wohl auch verbunden mit Spaltung auf Grund des Auseinanderbrechens der Kontinente und dem Beginn der Ausbreitung des Meeresbodens im früen Mesozoikum. 


\section{INTRODUCTION}

Upper Middle Ordovician carbonate rocks have a wide distribution in the Great Lakes region of Canada and the United States. They are present in the subsurface in the Michigan and Appalachian basins. From there they rise to the surface along the periphery of both tectonic elements to form an outcrop belt extending from the Adirondack region of New York State, through south-central Ontario, to the states of Michigan and Wisconsin (Douglas, 1969; Sanford and Baer, 1981).

In south-central Ontario, upper Middle Ordovician carbonate rocks onlap two major positive tectonic elements (Fig. 1), the Algonquin and Frontenac arches, both of which are known to have undergone vertical tectonic movements through successive periods of Precambrian and Paleozoic time (Sanford et al., 1985). To obtain a general understanding, as to the timing and magnitude of these movements, a field survey was carried out in 1992 to investigate one small segment of Paleozoic terrain where it onlaps Precambrian basement rocks of the Frontenac Arch between Head Lake and Burleigh Falls (Fig. 2). This segment of Paleozoic terrain was selected because of the variety of prominent surface and sub-surface lineaments that transect the region. Chief among these is the southwest-trending Central Metasedimentary Belt Boundary Zone (CMBBZ) that was tectonically active during the Grenvillian orogeny (Hanmer, 1988). This structural element is exposed on the Canadian Shield and continues to the southwest beneath the Paleozoic cover rocks. Other linear features (that may represent possible structural boundaries) are magnetic anomalies that, in general, parallel the NE-SW structural grain of the Central Metasedimentary Belt (Geological Survey of Canada, 1989). Finally there are linear topographical features, including the major drainage systems, superimposed on the Paleozoic terrain. These appear to have orientations similar to those of the surface lineaments in neighbouring segments of the Canadian Shield and are, thus, conceived as possible major fracture systems.

Prior to field investigations, the bedrock geology of the Head Lake-Burleigh Falls area was compiled onto modern 1:50,000 scale topographical maps (Energy, Mines and Resources, 1979, 1980) from geological maps prepared by officers of the Geological Survey of Canada (Caley and Liberty, 1952; Winder, 1954). Although mapped more than 40 years ago, the geological investigations proved to be of excellent quality in terms of accuracy, and required only minor revi-

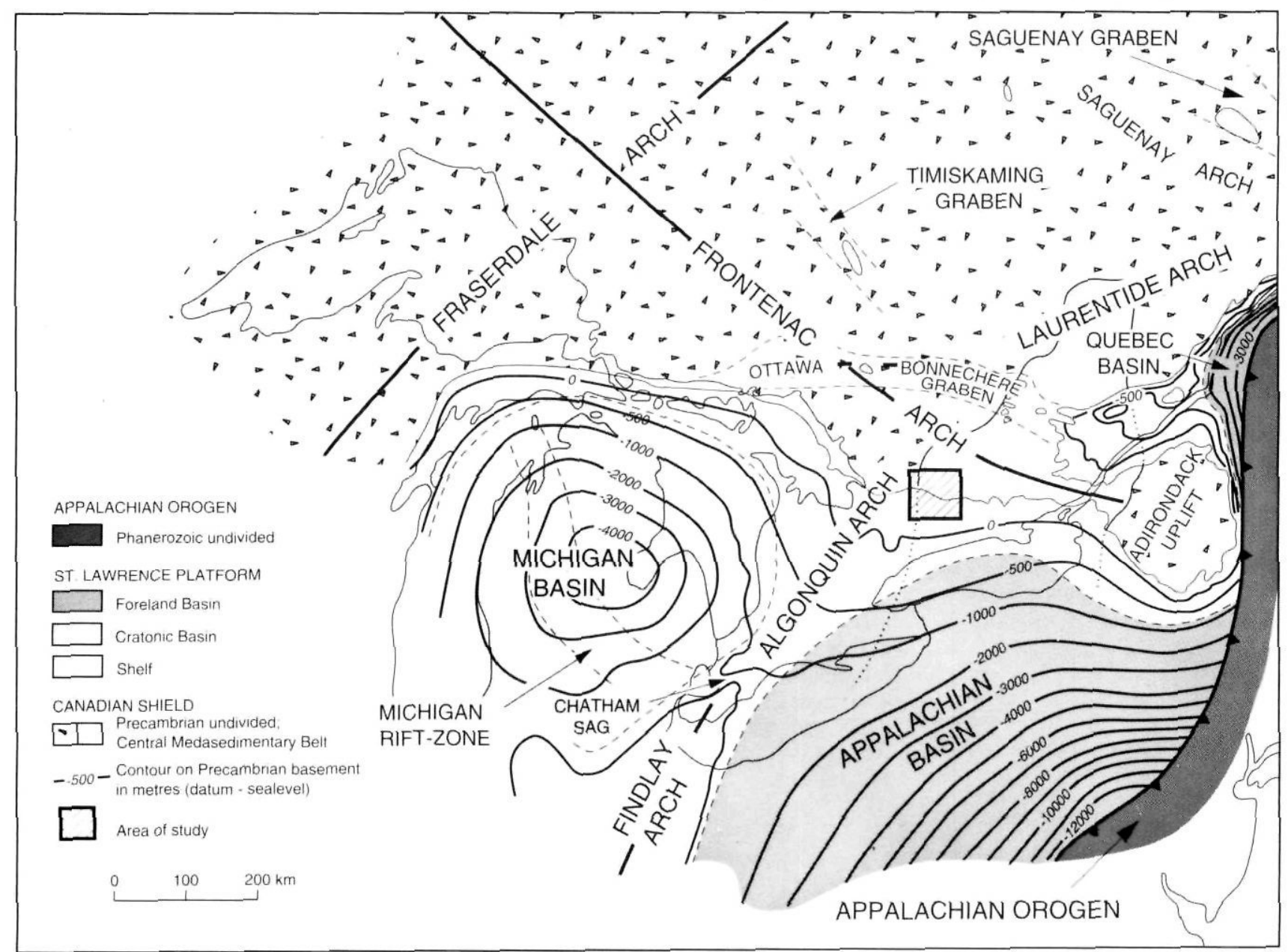

FIGURE 1. Principal Phanerozoic tectonic elements of the Great Lakes region.
Principaux éléments tectoniques phanérozoïques de la région des Grands Lacs. 
sions because of the many new road cuts and quarry operations that have been added to the data base in the intervening years.

The principal focus of the present field investigation was centred on the stratigraphic and structural framework of the Ordovician rock units where exposed along the PaleozoicPrecambrian contact and immediately adjacent areas to the south. This involved the identification and description of rock units (formations) and subunits, the recognition wherever possible of facies changes that may have been controlled by eustatic oscillations of sea-level, versus more local tectonic movement of the seafloor, and the identification of major fractures (faults) and other deformational features that could be directly applied to the reconstruction of the tectonic history and structural synthesis of the overall area.

In addition to a generally broad reconnaissance of the Head Lake-Burleigh Falls area (Fig. 2), 29 key sections were measured and described in detail in the field. The formation contacts and other "marker" horizons were identified to enable land surveyors to establish their precise elevations above mean sea-level. Thus, much new information has emerged in the Head Lake-Burleigh Falls area pertaining to late Middle Ordovician depositional processes, and late Precambrian to post-Middle Ordovician structural movements in general. This new information, when tied into the broader tectonic elements of the Great Lakes region, will hopefully provide a useful yardstick from which to measure the potential for any further tectonic movements that could conceivably occur in this, and adjacent, regions.

\section{REGIONAL TECTONIC SETTING}

The Ordovician rocks of the Head Lake-Burleigh Falls area form a small part of the St. Lawrence Platform, a major tectonic province of relatively flat lying Paleozoic strata that trend northeastward from the Great Lakes region of Canada and United States, through the Ottawa-Québec Lowland and the northern Gulf of St. Lawrence, to the west coast of Newfoundland. Throughout this region, the Paleozoic rocks are underlain, and bounded on the north, by Precambrian rocks of the Canadian Shield, and on the south by allochthonous rocks of the Appalachian Orogen. Along the southern margin of the platform, the strata have undergone major deformation (faulting and folding) by over-riding thrust slices transported during the Taconian, Acadian and Alleghanian orogenies. These episodes, controlled by plate tectonic events, triggered corresponding epeirogenic movements in wide regions of the St. Lawrence Platform, including that small segment of south-central Ontario to be discussed herein. Thus, to place the Head Lake-Burleigh Falls area and adjacent tectonic elements in a regional perspective, a review of the tectonic evolution of the St. Lawrence Platform is warranted (Sanford, 1993a).

Evolution of the St. Lawrence Platform and its periodic marine connection across the Canadian Shield with the Hudson and Interior platforms, were undoubtedly controlled by Paleozoic plate tectonic events in motion along the eastern margin of the North American continent. For the sake of simplicity, these events are grouped into two tectonic cycles: Cycle I, extending from late Precambrian to late Paleozoic,
FIGURE 2. Palaeozoic geology of the Head Lake-Burleigh Falls area (see Fig. 3 for stratigraphic ranges of key sections and Figs. 12 to 15 for structure sections).

Géologie paléozoïque de la région de Head Lake-Burleigh Falls (répartition stratigraphique à la fig. 3 et coupes structurales aux fig. 12 à 15).

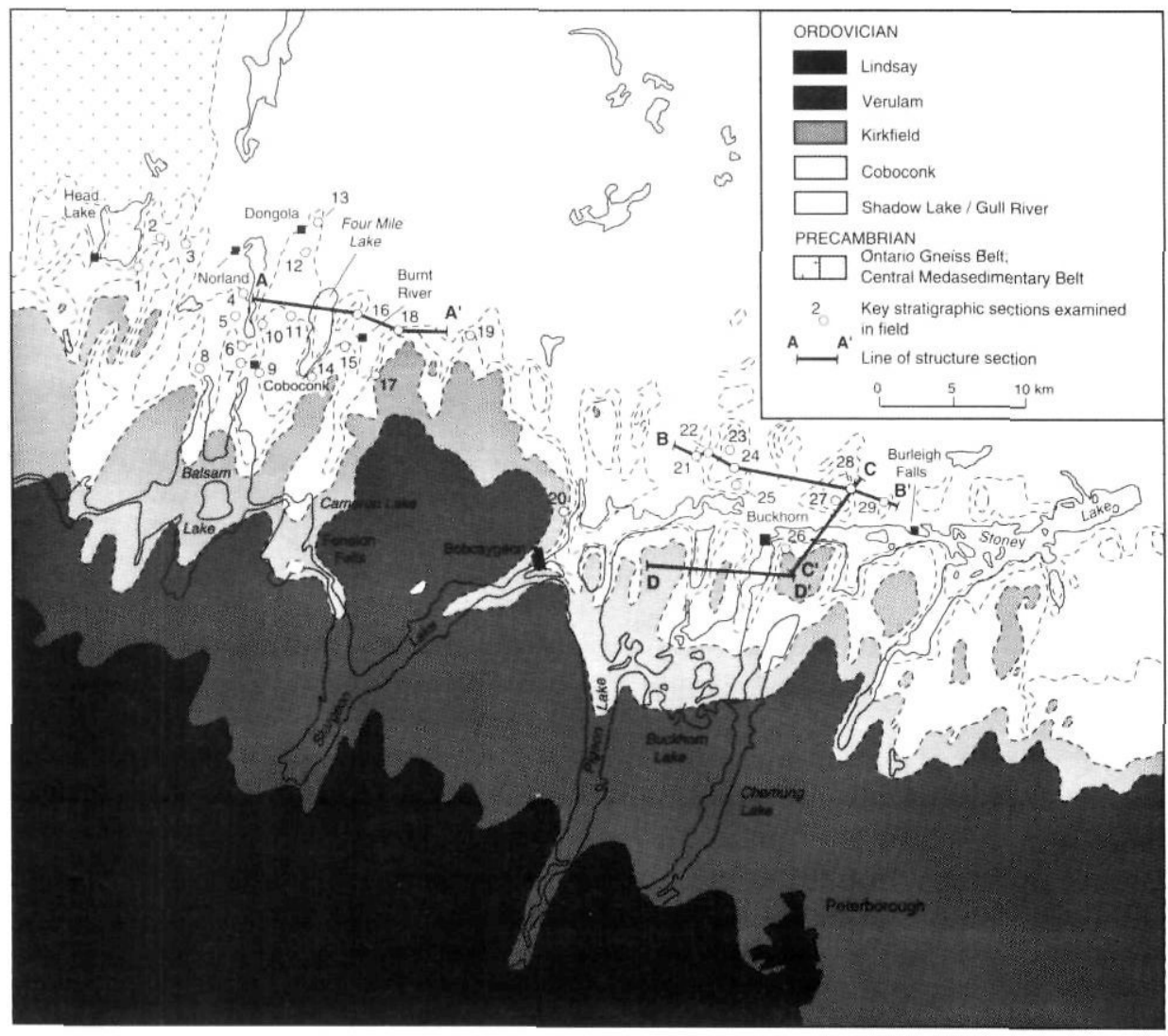

Geographie physique et Quaternaire, 47(3), 1993 
and Cycle II, active from early Mesozoic to present (Sanford et al., 1985.

Cycle I began with rifting in the late Precambrian to Early Cambrian (Williams, 1979; Wilson, 1966) leading to the eventual separation of the continental masses (opening of lapetus) in the Early Cambrian and continuing through the Cambrian and Early Ordovician. In the late Early and early Middle Ordovician, lapetus began to contract, with final closing and continental collision (?) occurring in the middle to late Paleozoic. Tectonic Cycle II began with Triassic rifting, followed by continental separation in the middle Jurassic to middle Cretaceous, with corresponding passive margin subsidence continuing to present.

Rifting and separation of the continents at the onset of Cycle I resulted in widespread block faulting and continental redbed deposition, and dyke and pluton emplacement over a wide region of what is now the St. Lawrence Platform and adjacent craton. Remnants of these strata are preserved in the Eastern, Central and Western divisions of the St. Lawrence Platform, and particularly so along the margins of the Frontenac Arch and its southeastern extension, the Adirondack Uplift (Fig. 1).

As rifting gave way to seafloor spreading processes in the mid-Early Cambrian, craton-derived clastics and carbonates were deposited on a broad continental shelf open to the southeast, a process that continued to near the end of Early Ordovician time. With the onset of convergence, first documented in the early Middle Ordovician, destruction of the outer continental shelf and slope, and building of the Appalachian Orogen began.

Coincident with this early Middle Ordovician Taconian event was widespread epeirogeny in the Western and Central divisions of the St. Lawrence Platform. It was expressed in the form of uplift, block faulting and subaerial erosion of Cambrian and Lower Ordovician sequences along the axes of the Frontenac, Algonquin and Laurentian arch systems. Besides rejuvenating the positive tectonic elements, the epeirogeny triggered the inception of the Michigan Basin in the late Early to early Middle Ordovician (Fisher and Barrett, 1985). It also established an elongated subbasin along the east side of the Frontenac Arch in a seaway that eventually extended from the Ottawa Embayment across the southern Canadian Shield to connect with the Hudson Platform.

The first widespread transport of orogen-derived clastics towards the St. Lawrence Platform was also in the early Middle Ordovician. These clastics were deposited into an elongated trough (St. Lawrence Marginal Trough) forming along the leading edges of advancing Taconian allochthons. As the structural front continued to advance in the late Middle to Late Ordovician, and over-ride the southeastern extremities of the Frontenac and Saguenay arches, the St. Lawrence Marginal Trough became segmented into three foreland basinal elements, the Anticosti, Québec and Appalachian basins from east to west, respectively. The Middle to Late Ordovician rejuvenation of the Algonquin, Frontenac and Laurentian arches in the Western and Central divisions of the St. Lawrence Platform coincided with the mid to late phases of the Taconian orogeny.
The widespread marine inundation of the craton that accompanied the Taconian orogeny continued into the Early Silurian, but was suddenly halted in the late Llandovery to early Wenlock by widespread uplift and block faulting. This very intensive epeirogenic event is recorded throughout most of North America, and may correspond to an early phase of continental collision and onset of the Acadian orogeny. The Ottawa-Bonnechere, Timiskaming and Saguenay grabens (Fig. 1), long considered to have been formed in the Mesozoic (Kay, 1942), more than likely had their origins during this early phase Acadian orogenic event.

Renewed uplift of the major arch systems intersecting and bordering the St. Lawrence Platform and the Hudson Platform to the north, along with corresponding accelerated basin subsidence and highly restricted seaways near the close of the Early Silurian, provided a suitable environment for the deposition of evaporites, reef-bearing carbonates and siliciclastics in basinal areas. This condition prevailed intermittently through succeeding Late Silurian and Devonian times. Later Acadian and Alleghanian orogenic events were probably responsible for the major deformation that occurred in parts of south-western Ontario at the close of the Silurian (Pridolian), in the Middle Devonian (Eifelian-Givetian), and post-Devonian (?) time, as a consequence of salt dissolution and collapse, a phenomenon triggered by the periodic rejuvenation of major fracture systems, accompanied by the introduction of formation and/or meteoric fluids.

On stabilization of the Appalachian Orogen, following the late Paleozoic Alleghanian orogeny, a new tectonic cycle (Cycle II) was initiated by Triassic rifting, and middle Jurassic to middle Cretaceous continental separation. The St. Lawrence Platform, located some distance from the newly forming Atlantic Continental Margin in the early Mesozoic, may not have undergone the very intensive deformation and deposition of clastics that accompanied the initiation of Cycle I. Nevertheless, there is clear evidence of Mesozoic rifting here and there along the platform in the form of dyke and pluton emplacement. The presence of Jurassic terrigenous clastics in the Michigan Basin (Sanford et al., 1979), and Jurassic to Cretaceous clastics in the Moose River and Hudson Bay basins and adjacent deep channels through Hudson Strait and Foxe Channel (Sanford and Grant, 1990), point to widespread epeirogeny of the central Canadian craton throughout much of the Mesozoic.

The basement arches, most of which have risen intermittently throughout the Phanerozoic, are still active, as evidenced by the concentration of earthquake epicentres that appear to parallel their axes in various segments of the Canadian craton (Sanford et al., 1985). This is especially so of the Frontenac Arch, and the structurally related Adirondack Uplift, that have had a long and complex history of tectonic rejuvenation. Adding to the complexity of the regional tectonics of the arch, and adjacent platformal regions which it intersects, is the Central Metasedimentary Belt (CMB) of the Grenville Province of the Canadian Shield (Fig. 1). These rocks cross the Frontenac Arch northwest of the Adirondack Uplift. From there their structural trend is NE-SW beneath the Paleozoic cover rocks of the Ottawa Embayment and 
Appalachian Basin respectively. The succession of epeirogenic movements that have affected the Frontenac Arch have thus, in turn, locally fractured the Paleozoic cover rocks in orientations that have a tendency to favor the southwest trending structural grain of the underlying rocks of the CMB. Some of these fractures extend for considerable distances into Paleozoic terrain in the Prince Edward County area of southcentral Ontario, and possibly beneath the adjacent waters of Lake Ontario (McFall and Allam, 1991). Contemporary movement of one or another of these could conceivably have been responsible for the earthquakes reported in western New York State, the Niagara Peninsula and adjacent locations beneath Lake Erie and southwestern Ontario. Thus far, earthquakes in south-central Ontario have been few and of low magnitude. The fractures that intersect Ordovician strata in the Head Lake-Burleigh Falls area are thought to be fairly numerous, and to have had a complex history of origin and development, as described later in the present text. To further determine, or otherwise speculate as to whether any of these fractures have potential for immediate or long-term rejuvenation, were not within the terms of reference of the writer's present investigation.

\section{STRATIGRAPHIC FRAMEWORK}

The upper Middle Ordovician rocks of the Head LakeBurleigh Falls area of south-central Ontario are underlain, and bounded on the north, by highly deformed metamorphic rocks of the Canadian Shield (Grenville Orogen). From their northern eroded edges the beds dip gently south to southeastward, towards the Appalachian Basin, at less than 5 $\mathrm{m} / \mathrm{km}$ (Figs. 1 and 2). Detailed geological mapping and stratigraphic studies of the area have been carried out by a number of workers over the years. Some of the more comprehensive of these have been by Okulitch (1939), Caley and Liberty (1952), Winder (1954) and Liberty (1969). Although much general agreement has been achieved by the above authors in the identification of mappable rock units in the field, there has been marked difference of opinion in the application of stratigraphic nomenclature. For the purpose of this paper, the writer has settled on a combination of rock unit terms as pro- posed by Okulitch (1939), and Liberty (1969) - namely Shadow Lake, Gull River, Coboconk, Kirkfield, Verulam and Lindsay formations in that respective stratigraphic order of succession. Their distribution, as adapted from Caley and Liberty (1952), Winder (1954) and Liberty (1964) is shown in Figure 2. Most of the of the writer's investigation was focused on the Shadow Lake, Gull River and Coboconk formations. These units were emphasized for two principal reasons. Firstly, they are well exposed along the prominent Paleozoic escarpment between Head Lake and Burleigh Falls, whereas the succeeding Kirkfield, Verulam and Lindsay formations are more heavily drift covered and, thus, largely obscured. Secondly, the contacts of the Shadow Lake, Gull River and Coboconk formations and their contained facies boundaries can be consistently traced for considerable distances along the Paleozoic escarpment, a factor which greatly facilitated the piecing together of the stratigraphic framework and the interpretation of the structural geology of the area.

In addition to the aforementioned Ordovician rock units, there is a possible remnant of the late Precambrian to Early Cambrian (?) Covey Hill Formation preserved at a single locality near Burleigh Falls, hitherto unreported in the geological literature (Station 29; Figs. 2 and 5). Although very limited in areal distribution, its presence here could add an important component to the reconstruction of the tectonic history of the Head Lake-Burleigh Falls area of south-central Ontario.

During the course of the present investigation, twenty-nine key sections were examined in the field, the locations and stratigraphic range of which are shown in Figures 2 and 3 respectively.

\section{COVEY HILL FORMATION}

The name Covey Hill Formation was originally proposed by Clark (1967) for the coarse red and grey feldspathic sandstones, quartz sandstones and conglomeratic sandstones typically exposed along the northern rim of the Adirondack Uplift in northern New York State, and extending into the adjacent area of Québec. The term was later applied to similar redbed sandstones and conglomerates in the Ottawa Embayment by Williams and Wolf (1982), and Williams et al.,
FIGURE 3. Stratigraphic ranges of key sections (see Fig. 2 for locations).

Étendue stratigraphique des coupes clés (localisations à la fig. 2).

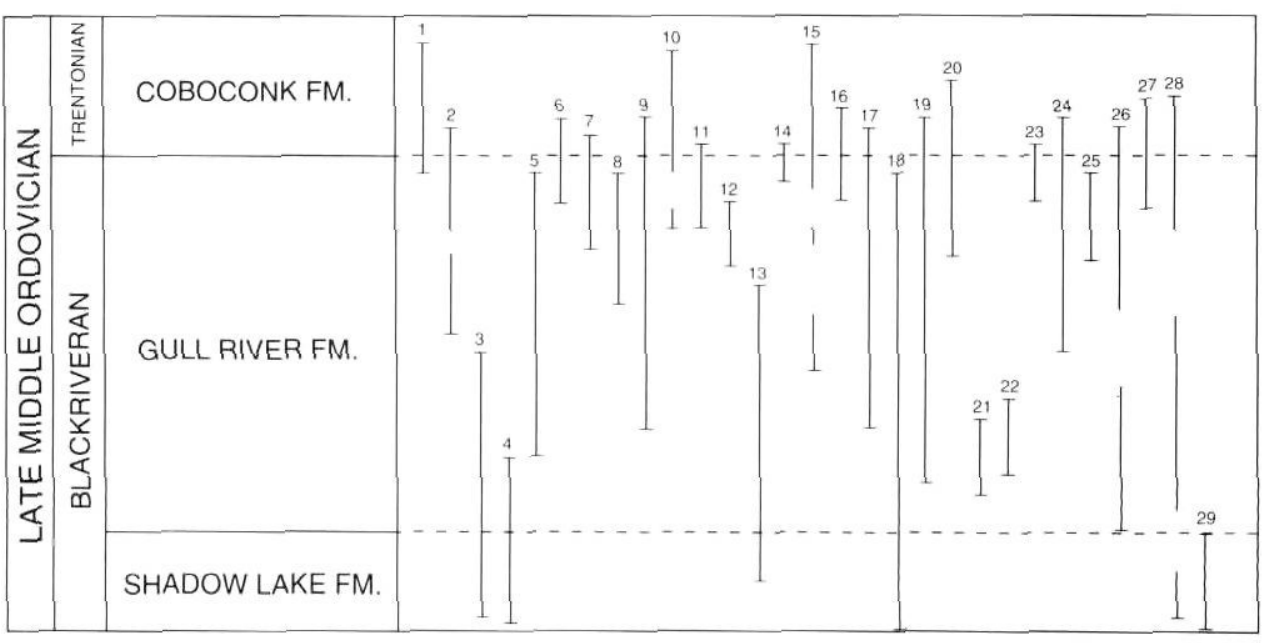

Géographre physique et Quaternaire, 47(3), 1993 
(1984), and to beds of largely identical composition referred to the Potsdam Formation by Winder and Sanford (1972) where they are exposed along the southwestern margin of the Frontenac Arch in south-central Ontario bordering the St. Lawrence River.

The presence of Covey Hill strata in the Head LakeBurleigh Falls area, so far as is known by the writer, is confined to a single roadcut exposure at Station 29 (Figs. 2 and 4), approximately three kilometres west of Burleigh Falls on Highway 36 . There the beds consist of coarse red and green quartz/feldspar conglomerate that forms a thin wedgeshaped deposit, 0 to $0.4 \mathrm{~m}$ thick, which rests unconformably on highly foliated, fractured and deeply weathered Precambrian crystalline rocks. They are, in turn, unconformably succeeded by redbed shales and carbonates of the upper Middle Ordovician Shadow Lake Formation.

Because of the very limited distribution of the Covey Hill beds in the study area, their stratigraphic relationship with possibly equivalent strata present elsewhere along the margins of the Frontenac Arch and Adirondack Uplift is highly obscure. In the latter areas the beds are thought to be largely fluvially transported detritus onto an alluvial plain (Hofmann, 1972) where they presumably accumulated in a continental environment of deposition. The Covey Hill beds in the study area probably have a similar origin, although their provenance and means of mechanical transport and original area of distribution will likely never be known.

\section{SHADOW LAKE FORMATION}

The name Shadow Lake Formation was proposed by Okulitch (1939) for the approximately $6 \mathrm{~m}$ of basal Ordovician shales and associated carbonates exposed in a small abandoned quarry and adjacent road cut on Highway 35, approximately $5 \mathrm{~km}$ north of the town of Coboconk (station 4; Figs. 2 and 5). The formation, as initially defined, contains a lithology that has long been compatible with the Shadow Lake, as identified in sample cuttings and cores in the subsurface of south-western Ontario (Sanford, 1961). Consequently, the Okulitch definition is followed in this paper.

At the type section, Shadow Lake strata consist of brick red, recessive weathering, fissile shales at the base, succeeded by reddish-brown dolomitic limestone. These give way at the top to grey-tan, shaley red-stained, dolomitic limestone and calcitic dolostone, with grey-green shale interbeds. Beds of similar composition and thickness were measured near Head Lake (station 3; Figs. 2 and 5), and near Dongola (station 13; Fig. 2), except that in the latter locality the basal shales were completely obscured by drift cover. In fact, nowhere in the Head Lake, Coboconk or Dongola areas was the Shadow Lake - Precambrian contact exposed, but fairly reliable estimates of the overall thickness of the formation were obtained by hand-levelling from the nearby exposed subjacent Precambrian basement rocks through the drift covered interval beneath the exposed Shadow Lake beds.

At some point east of Dongola, the lower red shales of the Shadow Lake give place laterally to greyish-red and greenish-grey, fine-grained to conglomeratic orthoquartzitic

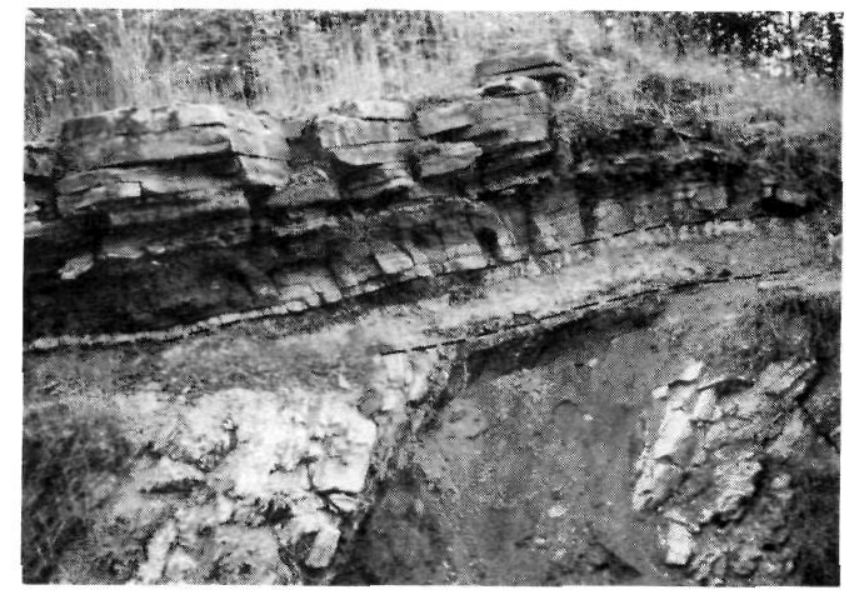

FIGURE 4. Quartz-feldspar conglomerate of the Covey Hill (?) Formation (identified by hachured lines) overlying foliated and sheared Precambrian rocks, and unconformably succeeded by shales and limestones of the Shadow Lake Formation, exposed on Highway $36,3.5 \mathrm{~km}$ west of Burleigh Falls at station 29 (Fig. 2).

Conglomérat à quartz et feldspath de la Formation de Covey Hill (?) (identifié par les tiretés) recouvrant des roches précambriennes cristallophylliennes cisaillées, suivies en discordance par des shales et des calcaires de la Formation de Shadow Lake, sur la route 36 , à $3,5 \mathrm{~km}$ de Burleigh Falls, au site 29 (fig. 2).

sandstone. These beds can be seen to good advantage just inside the entrance to Burnt River Quarries, Ltd., $2.5 \mathrm{~km}$ east of the village of Burnt River, where they are excavated for use as an ornamental stone (station 18; Figs. 2 and 5). In the main section of the quarry, located a few hundred metres to the south of the quarry entrance, the upper beds of the Shadow Lake are exposed in the floor and lower quarry walls. These consist of dove-grey lithographic limestone in a single bed, succeeded by massively bedded, greenish-grey, red-stained argillaceous and silty dolostones.

For some distance to the east of the Burnt River area, (between stations 19 and 21; Fig. 5) Ordovician strata are relatively inaccessible by road and, because of the limited time available, they were not examined during this study. However, Shadow Lake beds in total, or in part, are exposed in outliers north and east of Buckhorn, the most complete sections being located on Highway 36, a short distance west of Burleigh Falls at stations 28 and 29 (Figs. 2,5 and 6). There, the formation contains a somewhat thicker basal redbed sequence than was seen elsewhere by the writer along the Paleozoic-Precambrian contact. It consists of minor quartzfeldspar conglomerate and dolostone at the base, succeeded by red shales, limestones, silty to sandy limestones, and dolomitic limestones. The redbed sequence is, in turn, overlain by limestones, in part sandy and shaley, that are micritic (lithographic) in texture and contain an intervening massive layer $(0.45 \mathrm{~m})$ of coarse, greenish-grey and red, quartzfeldspar conglomerate, as illustrated in the Burleigh Falls composite stratigraphic column of Figure 5.

The relatively unfossiliferous beds of the Shadow Lake Formation were the initial deposits of the late Middle Ordovician sea, as it slowly encroached upon the undulating 


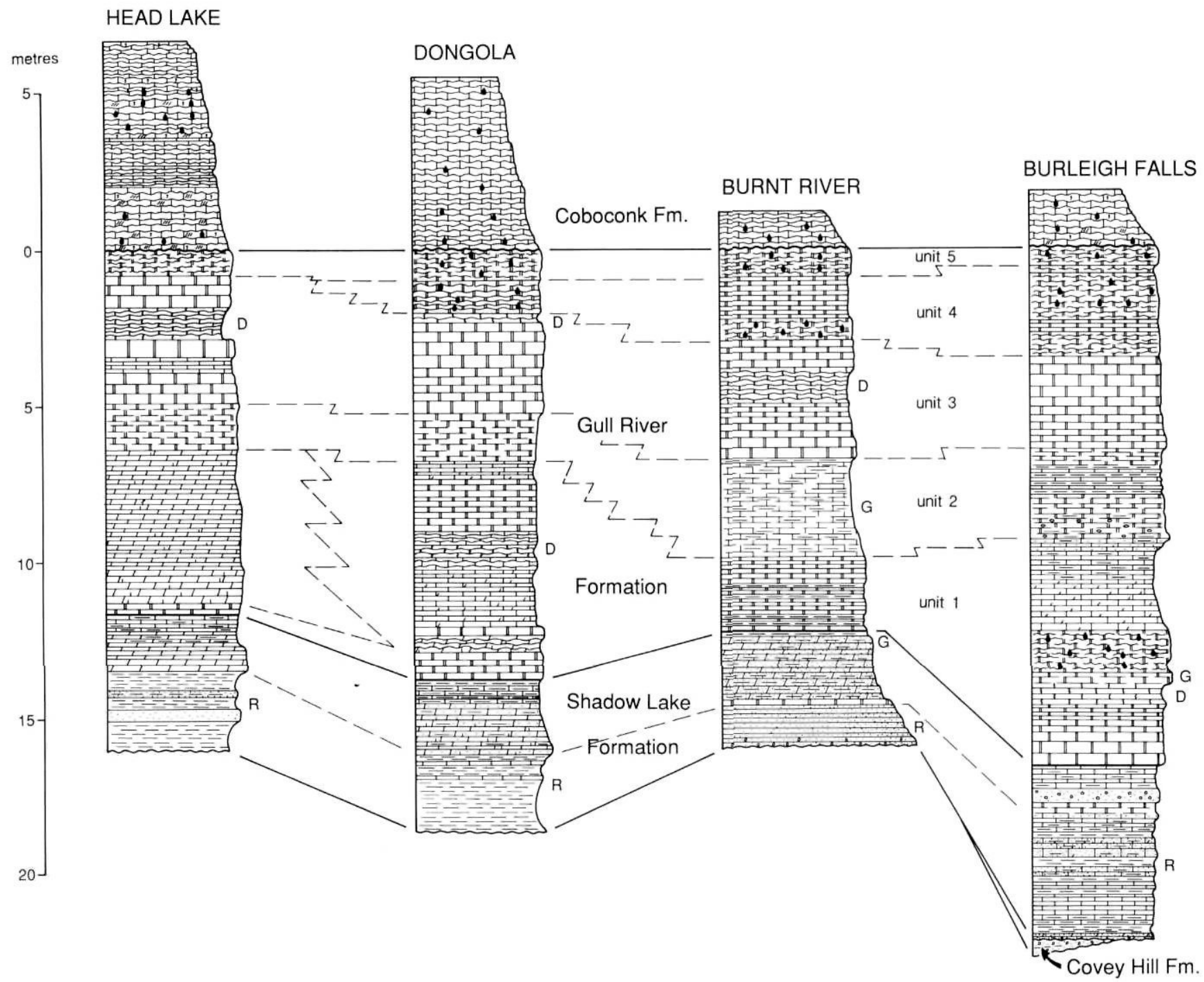

\section{FACIES AND ASSUMED DEPOSITIONAL ENVIRONMENTS}

Gypsum / lenses / crystal molds

OPEN PLATFORM MARINE (SUBTIDAL)

"प्राप्य Lithographic to coarse crystalline algal limestone

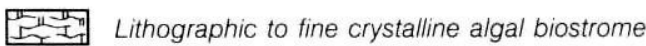

OPEN PLATFORM MARINE TO MARGINAL MARINE (SUBTIDAL TO INTERTIDAL)

Lithographic to medium crystalline limestone

Lithographic to fine crystalline laminated limestone

SEMI-CONTINENTAL / MARINE (SUBTIDAL TO SUPRATIDAL)

Lithographic hackly fractured limestone

Fine to medium crystalline dolostone

E-A Shale / siltstone

:0. Sandstone / conglomerate

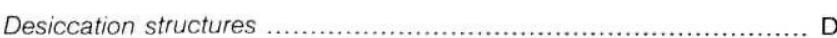

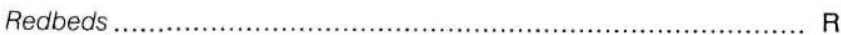

Abundantly fossiliferous ........................................................ •

Bioclasts / calcarenite .........................................................

Cross bedding...............................................................

FIGURE 5. Stratigraphic succession in the Head Lake-Burleigh Falls area. A) Stratigraphic columns for the Head Lake, Dongola, Burnt River and Burleigh Falls sections. B) Legend for Figure 5A and Figures 12 to 15.

Succession stratigraphique dans la région de Head Lake-Burleigh Falls. A) Stratigraphie des coupes de Head Lake, Dongola, Burnt River et Burleigh Falls. B) Légende de la figure $5 \mathrm{~A}$ et des figures 12 à 15 . 


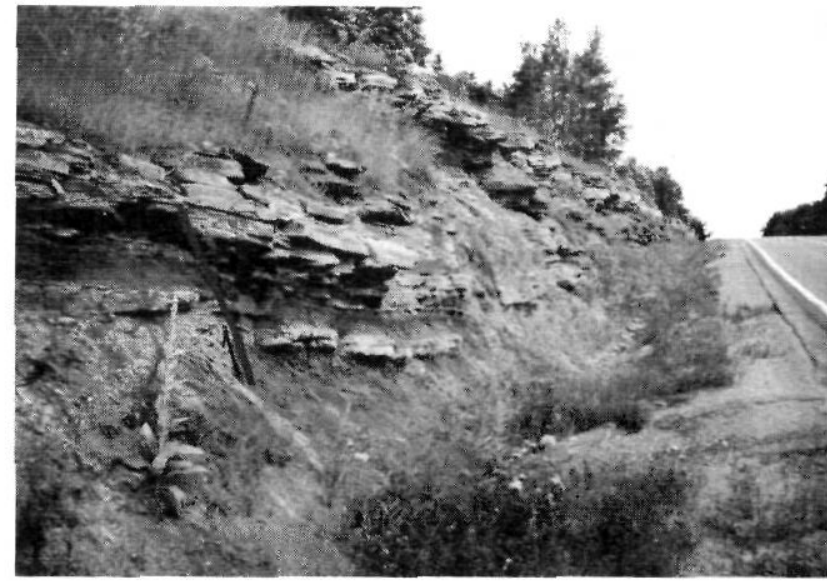

FIGURE 6. Shales and limestones of the Shadow Lake Formation overlying deeply weathered Precambrian rocks, exposed on Highway 36, $3.5 \mathrm{~km}$ west of Burleigh Falls at Station 29 (Fig. 2). Note normal fault intersecting Precambrian and lower beds of the Shadow Lake Formation.

Shales et calcaires de la Formation de Shadow Lake, recouvrant des roches précambriennes très altérées, sur la route $36,3,5 \mathrm{~km}$ à l'ouest de Burleigh Falls, au site 29 (fig. 2). Noter la faille normale recoupant la couche précambrienne et les couches inférieures de la Formation de Shadow Lake.

to highly irregular landsurface of the Canadian Shield. The siliciclastic content of the basal redbed facies is presumably the product of fluvially transported clay, silt, sand and pebble size detritus from the adjacent Shield to inner shelf margins of the seaway, where they accumulated in high intertidal to supratidal zones. The succeeding shaley to silty and sandy carbonates of the Shadow Lake were presumably also deposited high along the inner shelf of the advancing seaway in environments that possibly varied from intertidal to subtidal.

Shadow Lake beds, in the extreme western part of the map area between Head Lake and Dongola, are of relatively uniform composition, and one can only conclude that the Precambrian basement complex (CMBBZ), upon which the strata were deposited was a uniformly flat, peneplaned surface. The significant facies changes, particularly within the basal Shadow Lake redbeds farther to the east (Fig. 5), however, suggest some local variation in the configuration of the platform upon which the sediments were deposited. At Burnt River and vicinity, for example, the basal redbed clastics thin and become coarse in texture, possibly reflecting a higher energy medium of transport and dissemination across a Precambrian basement "high", a positive feature that affected sedimentation processes well up into the succeeding Gull River Formation as shown in Figures 5 and 12.

In the extreme eastern part of the map area (Bobcaygeon to Burleigh Falls) the highly irregular Precambrian surface also locally affected sedimentation processes during deposition of the Shadow Lake, in addition to the succeeding carbonates of the Gull River and Coboconk formations. Precambrian rocks beneath the herein named Crane Creek outlier (at stations 27 and 28; Fig. 2, and identified on Fig. 13) were structurally high and emergent through much of late
Middle Ordovician time, and probably provided a source of some of the fine to coarse detritus to the immediately surrounding depositional medium. The thick layer of quartzfeldspar conglomerate, contained within the upper limestone member of the Shadow Lake at stations 28 and 29 (Figs. 2 and 5), may have been derived from such a source, as a direct response to renewed block-faulting during this particular period of geological time.

\section{GULL RIVER FORMATION}

The term Gull River Formation was originally proposed by Okulitch (1939) for beds that conformably overlie the Shadow Lake Formation, and are succeeded by strata that were named the Moore Hill Formation by the same author. The type section is a road side escarpment $3.5 \mathrm{~km}$ north of the town of Coboconk (station 5; Fig. 2). Liberty (1955) redefined the Gull River Formation, dropping the lower boundary to the top of the red shales of the Shadow Lake, and raising the upper boundary to include the Moore Hill beds of Okulitch. In this paper, and in accordance with Sanford (1961), and Winder and Sanford (1972), the lower contact with the Shadow Lake conforms with the definition proposed by Okulitch (1939), and the upper boundary coincides with the base of the Coboconk (Bobcaygeon), as proposed by Liberty (1955, 1969) (Fig. 5).

The Gull River formation, consisting largely of limestones, is well exposed along the Paleozoic escarpment between Head Lake and Burleigh Falls (Fig. 3), and is readily recognizable by its extremely fine (lithographic) texture and bluegrey weathering characteristics. From the vicinity of Coboconk and Dongola, eastward to Burleigh Falls, some five stratigraphic units (of informal status) have been tentatively identified. The boundaries of these units are undoubtedly time transgressive, as suggested by the hachured tie lines between the composite sections (Fig. 5).

Unit 1 is best developed in the Dongola-Coboconk (Fig. 7), and Burleigh Falls areas. There, it contains a variety of lithologies consisting largely of dove-grey to cream and grey-tan, lithographic to finely crystalline limestones, shaley to dolomitic in part, upwards to $7 \mathrm{~m}$ thick. In the intervening Burnt River area, the beds thin to $2.4 \mathrm{~m}$ and change laterally to brown, shaley, lithographic limestones containing interbedded grey-green shales. Throughout the Head Lake-Burleigh Falls area certain of the beds of unit 1 are sparsely to richly fossiliferous, whereas some intervals appear to be unfossiliferous and locally contain desiccation structures (hackly fracturing, mud cracks, etc.), laminated bedding and bladeshaped pseudomorphs of gypsum. West of Coboconk and Dongola, the limestones of unit 1 give place laterally to light grey and brown, finely crystalline dolostones, which are well exposed at station 3 (Figs. 2 and 8), and in a succession of road cuts on Highway 503 west of the village of Head Lake.

Unit 2 of the Gull River Formation is best developed in the Burleigh Falls and Burnt River areas where it is 2.9 and $3.2 \mathrm{~m}$ thick, respectively, thinning to $1.5 \mathrm{~m}$ or less at Dongola and Head Lake (Figs. 5 and 9). The beds consist, for the most part, of unfossiliferous, grey, lithographic to finely crystalline limestones that exhibit a characteristic laminated appearance 


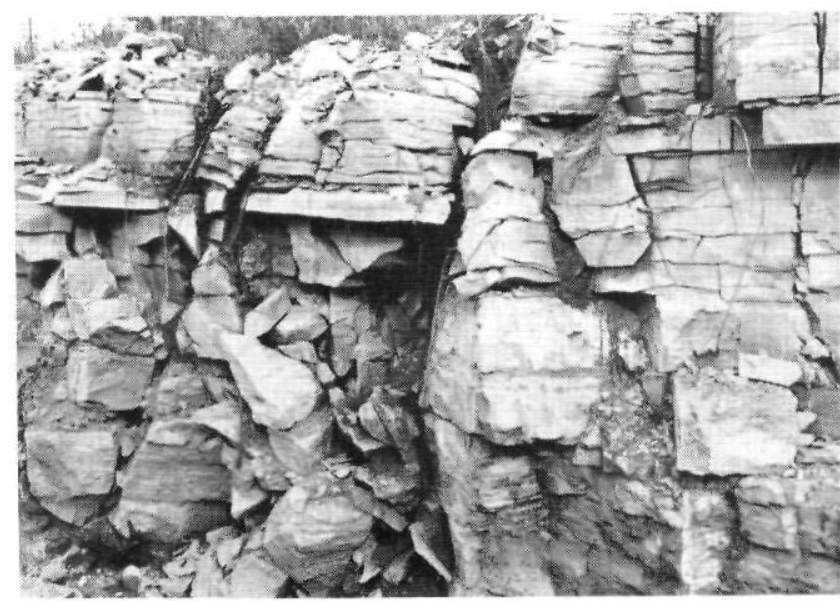

FIGURE 7. Lithographic limestones of unit 1 Gull River Formation, exposed on Highway 503 approximately $1 \mathrm{~km}$ east of Dongola. Note near vertical normal fault between scale markers.

Calcaire lithographique de l'unité 1 de la Formation de Gull River, sur la route $503,1 \mathrm{~km}$ à l'ouest de Dongola. Noter la faille normale quasi verticale entre les reperes.

on weathered surfaces. Terrigenous clastics in the form of shale partings and interbeds, quartz pebble conglomerate and gypsum nodules, or blade-shaped pseudomorphs of gypsum, are locally characteristic of the unit.

Unit 3, consisting of dove-grey to cream-colored, lithographic limestone, is similar in most respects to unit 1, except it is usually more massive-bedded and resistant to erosion. In combination with units 4 and 5 , unit 3 forms the crest of the prominent Paleozoic escarpment extending across southcentral Ontario. The strata are well exposed at a number of localities (Figs. 2,3,5 and 10) between Head Lake and Burleigh Falls where they maintain an average thickness of about $3.5 \mathrm{~m}$. The beds, as in much of unit 1, are sparsely fossiliferous and in some intervals apparently contain no recognizable organic material whatever.

Units 4 and 5 (presumably the Moore Hill beds as originally defined by Okulitch (1939)) are of similar lithological composition, but can be individually identified by their bedding and weathering characteristics for considerable distances along the crest of the Paleozoic escarpment between Coboconk and Burleigh Falls (Figs. 2,3 and 5). The beds consist of medium to dark brown lithographic limestones that are contained in thin and highly irregular beds that weather into thick, massive layers. They are highly algal in character (thus accounting for the irregular bedding) and are abundantly fossiliferous, particularly unit 5 . The combined units 4 and 5 thicken progressively in an eastward direction, partly at the expense of the underlying unit 4 , from $0.8 \mathrm{~m}$ at Head Lake to $3.5 \mathrm{~m}$ in the vicinity of Burleigh Falls. Similar increased thickening has also been noted as the beds are traced in a basinward direction towards Coboconk (stations 6-9; Fig. 2), and Buckhorn (station 26; Fig. 2). In each of the latter localities, the units (particularly unit 5) become increasingly fossiliferous, and locally contain interbeds of cross-bedded calcarenite and bioclastic limestone. Except for the aforementioned

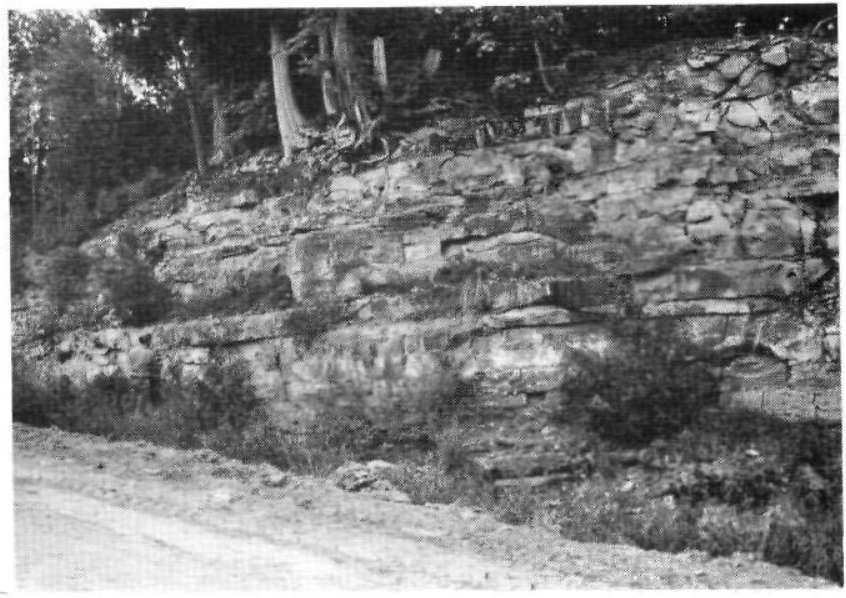

FIGURE 8. Medium crystalline dolomitized beds, equivalent to unit 1 , Gull River Formation, dipping at approximately $2^{\circ}$, to the west (left side of photo), at station 3 (Fig. 2).

Couches de dolomie moyennement cristalline, équivalentes de I'unité 1 , de la Formation de Gull River, s'inclinant d'environ $2^{\circ}$ vers l'ouest (à gauche), au site 3 (fig. 2).

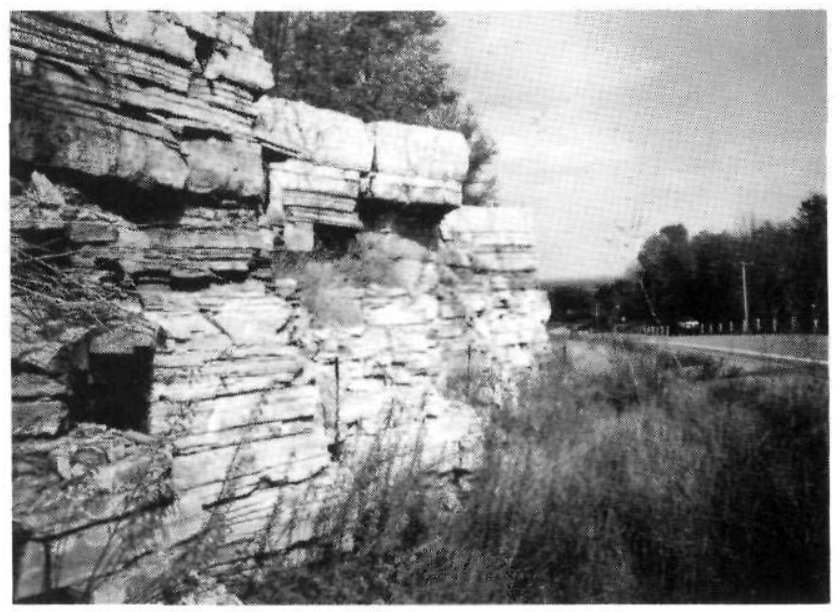

FIGURE 9. Laminated limestones and minor shales of unit 2, Gull River Formation, overlain by massive lithographic limestones of unit 3, on Highway 36, $6 \mathrm{~km}$ west of Burleigh Falls.

Calcaires en lamines et petite quantité de shales de l'unité 2, de la Formation de Gull River, sous-jacents à des calcaires lithographiques massifs, sur la route $36,6 \mathrm{~km}$ à l'ouest de Burleigh Falls.

local, fossil-bearing zones within unit 1 , fossils are relatively rare in lower and middle Gull River strata. In the upper beds, particularly units 4 and 5 , distinctive forms include Cryptophragmus, Tetradium, Bathyurus, endocered and actinocerid cephalapods, a few coiled gastropods, and brachiopods (Winder and Sanford, 1972)

When examined in some detail in the field, the Gull River Formation can be seen to display a complex relationship of subtidal to supratidal carbonate facies, attributable to a combination of environmental factors relating both to sea-level fluctuations and variations in the configuration of the seafloor upon which the sediments were originally deposited. Perhaps one of the best examples of the latter phenomenon can be 


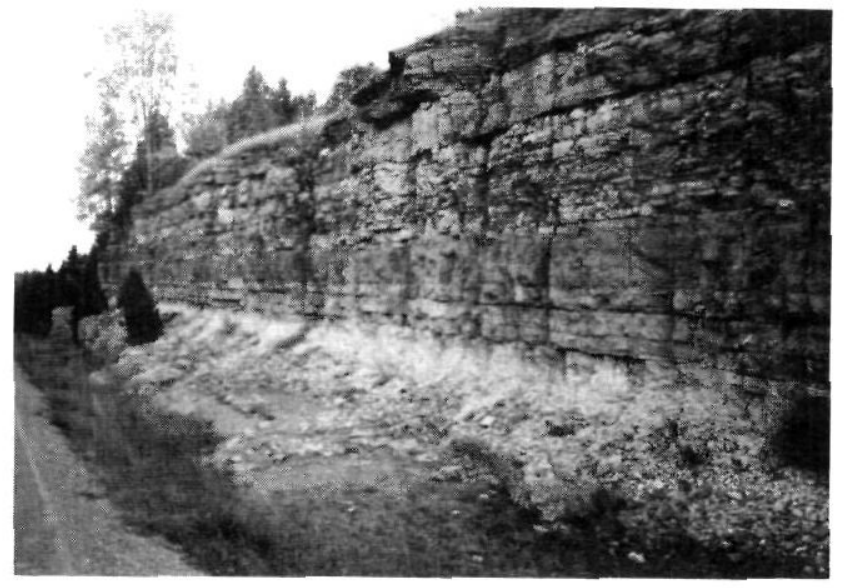

FIGURE 10. Lithographic limestones of the Gull River Formation overlain by fine to medium crystalline limestones of the Coboconk Formation, exposed on Highway 649 approximately $2 \mathrm{~km}$ south of its junction with Highway 121. Unit 3 Gull River (including the light colored rubbly zone) is shown in the lower and middle parts of the photo, overlain by units 4 and 5 at the top of the formation. Overhanging darker beds at the top of the section are Coboconk Formation.

Calcaires lithographiques de la Formation de Gull River recouverts par des calcaires cristallins à grains fins et moyens de la Formation de Coboconk, sur la route 649, environ $2 \mathrm{~km}$ au sud de l'intersection avec la route 121. L'unité 3 de la Formation de Gull River (y compris la zone très fragmentée en pále), apparaissant au bas et au centre, est recouverte par les unités 4 et 5 au-dessus de la formation. Les couches supérieures en surplomb sont de la Formation de Coboconk.

seen in the Burnt River area, as evidenced by the thinning of unit 1 , and corresponding facies change to laminated carbonates of unit 2 at a somewhat earlier stage of deposition than elsewhere in the Head Lake-Burleigh Falls area. This would appear to confirm the presence of a Precambrian basement high in this portion of the map area during deposition(?) of the Gull River, as was postulated earlier in this paper, to account for the local thinning and facies change of the basal redbed unit of the Shadow Lake Formation. Similarly, the abrupt change from unit 1 limestone to dolostone between Dongola and Head Lake, as shown in Figure 5, may also be related to a shallowing of the seaway approaching a structurally high, and partially emergent, Algonquin Arch to the west, accompanied by the influx of highly charged magnesium-bearing fluids into the depositional medium.

The progressive rise of sea-level that commenced with the deposition of unit 3 , and eventually concluded with the open platform marine (subtidal) facies of units 4 and 5 , served to obscure many of the last vestiges of irregularity that may have been present on the seafloor during Shadow Lake deposition and the initial periods of Gull River sedimentation. Some exceptions to this can be seen to have occurred in a few isolated parts of the study area, perhaps the best example being the Precambrian rocks within the Crane Creek outlier (stations 27 and 28; Figs. 2 and 13) that continued to be emergent throughout the Gull River period of deposition.

Following the deposition of unit 5 of the Gull River at, or near, the close of the Blackriveran Stage, the sea withdrew from south-central Ontario, initiating a brief period of subaerial erosion. At the onset of a renewed tectono-stratigraphic cycle, commencing in the early Trentonian, a succession of carbonate units was deposited under open-platform, marine conditions that reflected the rapidly changing Taconian orogenic activity in progress (rising tectonic land) along the continental margins of eastern North America. The rock units that comprise this succession in the Head Lake-Burleigh Falls area are the Coboconk, Kirkfield, Verulam and Lindsay formations in that stratigraphic order of succession (Fig. 2). Only the Coboconk Formation was examined in any detail (Fig. 3).

\section{COBOCONK FORMATION}

The term Coboconk was originally proposed by Johnston (1911) as a provisional name for the 3 to $6 \mathrm{~m}$ of "dark blue to grey nodular and cherty limestones" that underlie the Kirkfield in the vicinity of Coboconk. The terms Coboconk and Kirkfield were considered to have biostratigraphical connotations by Liberty (1969) and he, thus, abandoned both names and combined the two units under the new name of Bobcaygeon Formation. Because the Coboconk bears little, if any, lithological resemblance to the overlying Kirkfield strata in this region of south-central Ontario, the term Coboconk is retained in accordance with Johnston (1911), Okulitch (1939), Sanford (1961) and Winder and Sanford (1972).

Where mapped in the Head Lake-Burleigh Falls area (Figs. 2, 3 and 5), the Coboconk Formation consists of light brown to light grey and grey-tan, finely to coarsely crystalline limestone. The limestone occurs in thin nodular and wavy beds that weather into massive layers that are highly resistant to erosion. The strata, highly algal in content, are sparse to richly fossiliferous and locally contain interbeds of calcarenite and bioclastic limestone, that commonly show small scale cross-bedding. Some of the more characteristic fossils of the Coboconk include Stromatocerium, Tetradium, Doloroides, Sowerbyella, Triplesia, Eodinobolus, Maclurites, Goniceras, and Receptaculites (Winder and Sanford, 1972). Although the Coboconk is exposed at a moderate number of localities along the crest of the Paleozoic escarpment within the map area, perhaps the most complete section $(6.8 \mathrm{~m})$ is the roadcut on Highway 503, located approximately three kilometres east of the village of Head Lake (station 1; Figs. 2,3 and 5).

In sharp contrast to the dominant lithographic character of the Gull River limestones, that were somewhat limited in their areal distribution, are the coarser textured, richly fossiliferous limestones of the Coboconk and succeeding shaley limestones of Trentonian and Edenian age. These units were deposited over a wide region of the St. Lawrence Platform and adjacent craton under "high stand", open-platform, marine conditions. The broad lithological consistency and uniformity of thickness of the Coboconk, and subjacent units 4 and 5 of the Gull River, clearly confirm that deposition during these times took place on a broad, uniformly flat, marine platform that was gently subsiding to form the Appalachian Basin to the south. This finding is fundamental to determining the tectonic history of the region, particularly in terms of assessing the magnitude of post-Middle Ordovician crustal movements in the form of basement uplift and block faulting. 


\section{STRUCTURAL FRAMEWORK}

The upper Middle Ordovician Shadow Lake, Gull River and Coboconk formations were originally deposited across a broad segment of the southern Canadian Shield, and reduced to their present distribution by processes of subaerial erosion. Their erosional edges, which now form a major escarpment and cuesta, are carved into the Paleozoic strata in linear patterns that would appear to have been shaped in large part by basement tectonic movements during, and subsequent to, their original period of deposition.

In the eastern part of the map area (Bobcaygeon to Burleigh Falls), the erosional edge of the main body of Paleozoic strata forms a prominent east-west linear physiographic feature on the geological map (Fig. 2), where the beds onlap the southern flank of the Frontenac Arch. Immediately to the north is a series of outliers, neatly arranged in an east-west orientation, that closely parallels the main Paleozoic body to the south.

In contrast to the erosional features between Bobcaygeon and Burleigh Falls are the northeast-trending Paleozoic promontories between Head Lake and Burnt River, that are separated by major indentations of Precambrian terrain. The principal differences in physiographic character of the two areas are probably related to variations in their tectonic history in terms of uplift and block faulting. Although the Paleozoic terrain between Head Lake and Burnt River is locally deformed, apparently as a result of arch movements, the magnitude of the deformation (block faulting) appears to be less intensive than in the eastern part of the map area, between Bobcaygeon and Burleigh Falls.

In the piecing together of a fracture framework to account for the anomalous physiographic features of the Paleozoic and adjacent Precambrian terrains, the writer acquired access to, and examined in some detail, the satellite LANDSAT and radar imagery enlarged to $1: 250,000$ scale. These provided a valuable source of information for the identification and compilation of surface lineaments, some of the more prominent of which are shown in Figure 11. Most of the lineaments have excellent resolution in the thinly drift covered areas of the Canadian Shield, particularly on satellite radar imagery. In many instances the lineaments can be readily traced into Paleozoic terrain where they commonly coincide with prominent topographical features, including the major drainage systems. Although some of the lineaments shown in Figure 11 may be of questionable origin, most appear to be structurally controlled, and to represent the surface expression of major fracture sets.

Assuming that most of the features described above are major fractures, they are henceforth referred to as fracture lineaments. Where mapped from satellite imagery, the fracture lineaments show substantial variation in frequency and intensity of structural movement from place to place. The greatest numbers appear to be concentrated in the BobcaygeonBurleigh Falls area, where they trend both perpendicular and parallel to the Paleozoic-Precambrian boundary. One of the more spectacular linear features is the prominent east-west

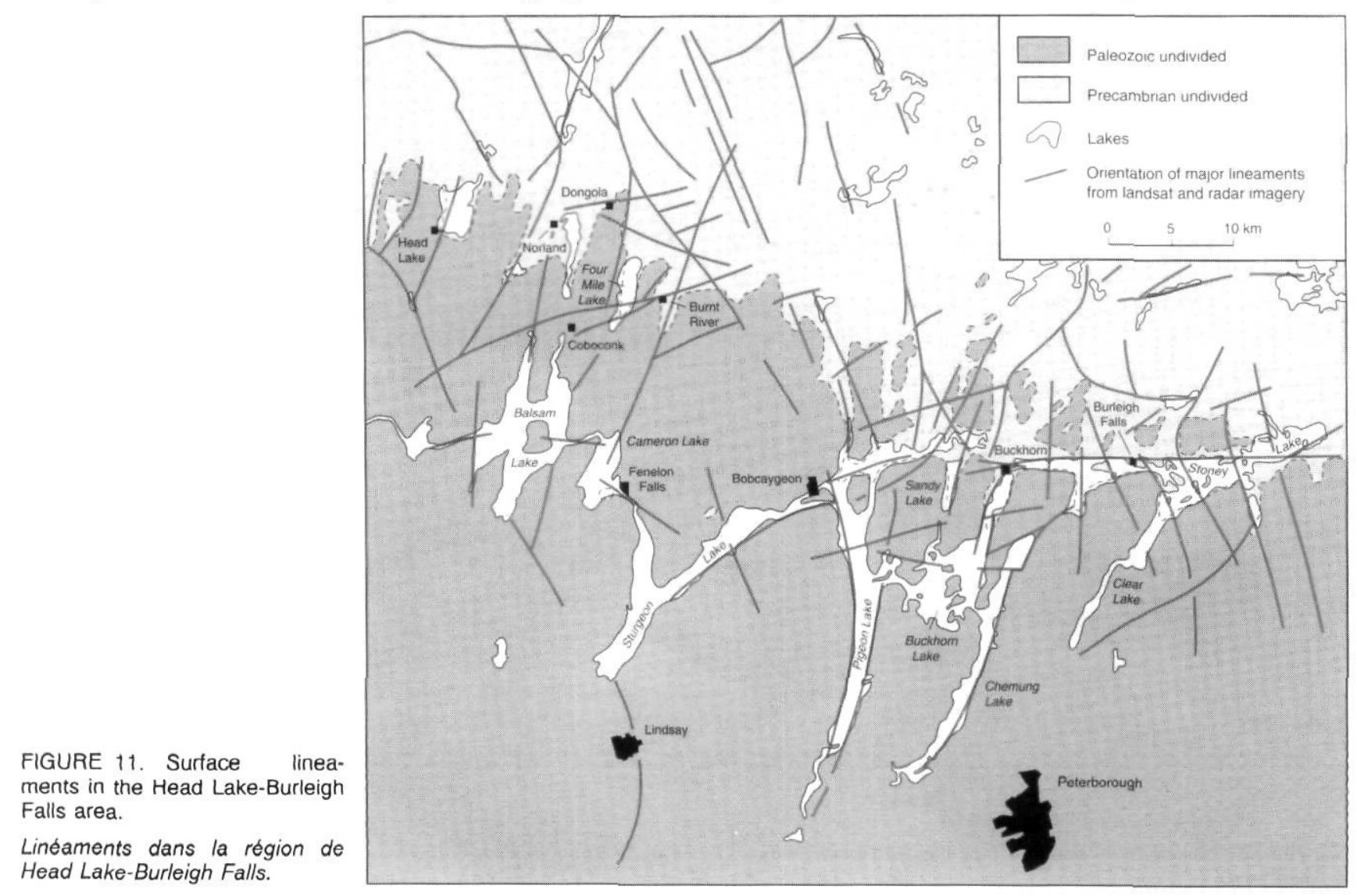

Head Lake-Burleigh Falls. 
fracture lineament that parallels the north shore of Stony Lake and Lower Buckhorn Lake, and eventually curves to the southwest where it coincides with the long axis of Sturgeon Lake. This fracture lineament may prove to be an important structural feature in having formed the hingeline along which the Precambrian basement to the north was uplifted, thus triggering the very intensive erosion of its Paleozoic cover rocks, and their eventual segmentation into outliers along fractures which strike both northeast and northwest. South of this prominent east-west structural dislocation, the fractures trend south and south-southeast, becoming curvilinear to the south-southwest, where they have a tendency to follow the axes of Pigeon and Chemung Lakes, and some of the adjacent smaller lakes and major stream systems.

Many of the surface lineaments that are moderately abundant in the Head Lake-Burnt River segment of the map area are also assumed to represent the surface expression of major fracture systems (faults). These favor a northeast orientation, though some trend to the northwest and west-southwest.

Because many of the fracture lineaments in the Head Lake-Burleigh Falls area, shown in Figure 11, coincide with the orientation of the major drainage systems (lakes, rivers and streams), the latter more likely to contain thick deposits of glacial drift, details of their vertical and/or horizontal displacements are often difficult, if not impossible, to document. Nevertheless, faulting (generally with less than one metre of vertical displacement) was documented in the field in 1992 at stations 12, 13, 16, 19, 21 and 29 (Fig. 2). Of the six, nearlyvertical normal faults recorded, four were found to be oriented in a southeast direction, and two to the southwest. At one of the stations (station 19), both the Gull River and Coboconk formations were intersected by southeast trending normal faults, in addition to strike-slip faults of similar orientation.

In addition to the major fractures that were directly observed at the aforementioned localities, there are numerous, small-scale structures where regional dips of the Shadow Lake, Gull River and Coboconk formations have been locally reversed. In some instances these form domal structures and are assumed to be attributable to drape over
Precambrian "highs". In many other instances, the beds are simply tilted and the cause is presumably attributable to faulting. Departure from regional dips, in the order of $3^{\circ}-5^{\circ}$, are common in some structures, with dips varying from $7^{\circ} .9^{\circ}$ being recorded at station 29 (Fig. 2) near Burleigh Falls.

Perhaps the most convincing evidence for the interpretation of post-late Middle Ordovician faulting of some major significance, beyond that of direct observation in outcrop, lies in the structural application of elevation data from topographical maps, and precise elevation measurements made by William R. Coe, Ltd. at 22 key locations on formation contacts and other marker horizons. These data confirm substantial variation in elevation of the Shadow Lake, Gull River and Coboconk formations, as they are traced from place to place across various segments of the map area. When used in combination with the stratigraphic framework and detailed geological maps (Caley and Liberty, 1952; Winder, 1954), superimposed on a suitably contoured, topographical base (Energy, Mines and Resources, 1979, 1980), it is possible to construct some semblance of two-dimensional structural models of the area, as illustrated in cross-sections $A-A^{\prime}, B-B^{\prime}$, C-C', and D-D' (Figs. 2 and 12 to 15).

In the western sector of the map area, structure section A-A' (Fig. 12) implies vertical movement along several of the north-south fracture lineaments identified in Figure 11. A prominent structural feature on line $\mathrm{A}-\mathrm{A}^{\prime}$ is a tilted fault block located between Four Mile Lake and Burnt River. Its elevated position above the regional attitude of Paleozoic strata, both to the west and east, is based on a combination of factors. These include a precise elevation of $303 \mathrm{~m}$ (relative to mean sea level) on the Gull River-Shadow Lake contact at station 16 (Fig. 2), a known thickness of approximately $17 \mathrm{~m}$ for the combined Gull River and Shadow Lake formations, and the approximate elevation of the Paleozoic-Precambrian contact on opposite sides of the block where plotted on the Fenelon Falls topographical map sheet (Energy, Mines and Resources, 1980).

In the eastern sector of the map area, structure section B-B' (Fig. 13), drawn in a west to east direction through the series of Paleozoic outliers, illustrates rather well the vertical

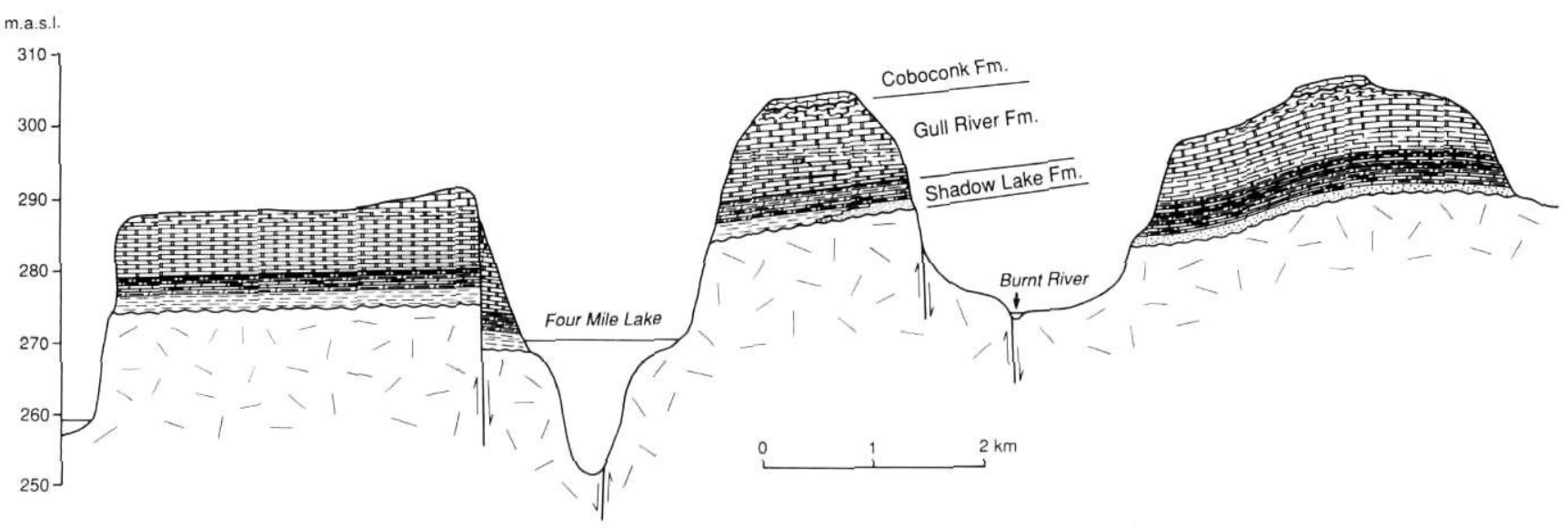

FIGURE 12. Structure section A-A' (see Fig. 2 for location and Fig. Coupe structurale A-A' (localisation à la fig. 2 et légende à la fig. 5B). $5 B$ for legend). 
dislocation that has taken place along the north-south fractures that led to the segmentation of the strata following Coboconk deposition. The variation in elevation of the principal outliers identified in this line of section is based on information from measured sections 21-29 inclusive (Fig. 2), keyed to precise elevations of selected formation contacts and other key horizons where exposed to good advantage. These were supplemented with spot elevations and contour data from the Burleigh Falls map sheet (Energy, Mines and Resources, 1979). At one locality (station 27; Fig. 2) within the Crane Creek outlier, Gull River and Coboconk strata can be seen to stratigraphically onlap Precambrian granitic rocks, clearly indicating the Precambrian "high" was in place prior to late Middle Ordovician time. However, the Shadow Lake, Gull River and Coboconk formations contained within the Crane Creek outlier are topographically higher than equivalent strata of the Deer Bay Creek outlier to the east, and the Flynns Turn outlier to the west. They were, thus, structurally elevated at some post-Middle Ordovician point in time.

In contrast to the relatively moderate levels of basement adjustment noted by the writer throughout most of the Head Lake-Burleigh Falls area, is the $\mathbf{3 0 ~ m}$, or more, of vertical displacement along the Stony Lake fracture lineament separating the Crane Creek outlier from the main Paleozoic body to the south (Section C-C'; Figs. 11 and 14). Much of the surface expression of Section C-C' and the elevation of formation contacts were extrapolated from the Burleigh Falls topographical map sheet (Energy, Mines and Resources, 1979), and surface elevation (243 m) of Lower Buckhorn Lake. Precise elevation measurements on the Gull River/Coboconk contact, at stations 26 and 27 (Fig. 2), of $312 \mathrm{~m}$ and $274 \mathrm{~m}$ respectively, confirm the abrupt variation in elevation of the strata, as illustrated in Figure 14, across the east-west trending Stony Lake fracture lineament.

The roughly north and northeast to northwest-trending fractures, along which block movement and fracturing of overlying Paleozoic strata occurred north of Lower Buckhorn and Stony Lakes (Section B-B'; Fig. 13), are not as well documented in areas immediately to the south. This is due to the too few precise elevation measurements on key stratigraphic horizons from which to confirm the structural configuration of

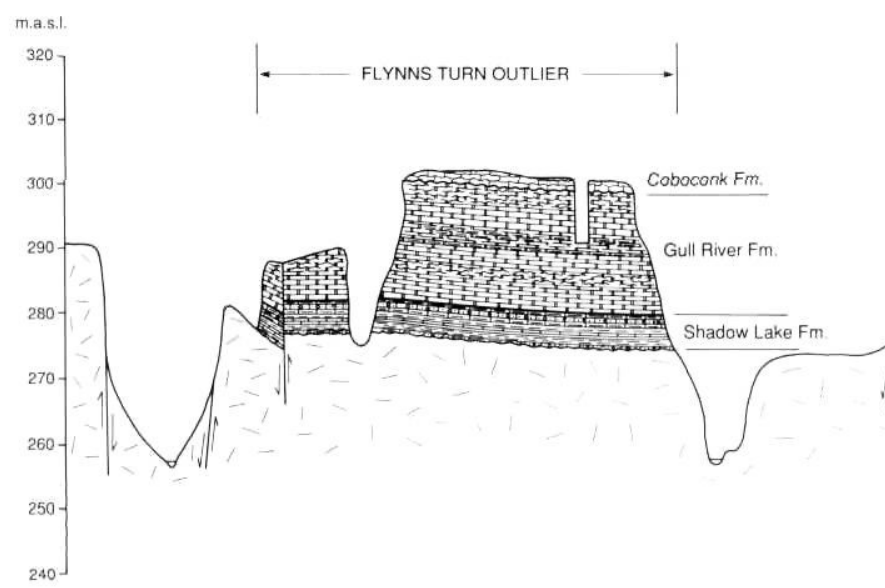

FIGURE 13. Structure section B-B' (see Fig. 2 for location and Fig. $5 B$ for legend). the Shadow Lake, Gull River and Coboconk formations in cross-section. However, faulting can be inferred at a number of localities from information currently available. Perhaps one of the better examples where stratigraphic framework combined with a bedrock geological map keyed to topographical contours, can be applied to infer fault-block movement is the fault-bounded segment between Sandy Lake and Buckhorn Lake (Section D-D'; Fig. 15).

The basic stratigraphic and structural framework, pieced together from field and subsurface studies, lead to some general inferences with regard to the Paleozoic, and later, tectonic history of the Head Lake-Burleigh Falls area. In one place or another, six tectonic events, that vary from mild to fairly intensive, have been noted or inferred by the writer. The first, and perhaps one of the more intensive and widespread tectonic event, is assumed to have occurred in late Precambrian Hadrynian to early Early Cambrian (?) times. This event is associated with the rift tectonics that led to the initial pulling apart of the continental masses (Sanford (i), in press), and the widespread deposition of continental redbeds in broad regions of the St. Lawrence Platform and adjacent craton. This epeirogeny, in all probability, affected much of south-central Ontario including the Head Lake-Burleigh Falls area where it locally elevated and tilted basement blocks, thereby providing provenance for the dispersal of quartzfeldspar conglomerate of the Covey Hill Formation (Fig. 2). The elevated Precambrian block beneath the Crane Creek outlier (stations 27 and 28; Figs. 2 and 13), and several other high Precambrian features, where they protrude through the Paleozoic (Fig. 2), may have had their origins in part during this major tectonic event.

The second significant tectonic event took place in the early Middle Ordovician, resulting in the uplift of the Algonquin and Frontenac arches, and widespread removal of Upper Cambrian and Lower Ordovician strata along their axes by processes of subaerial erosion (Sanford, 1993a). The present edges of these strata, where mapped in the subsurface (Sanford and Quillian, 1959), were deeply bevelled by erosion and, in many localities, particularly along the southeastern margins of the Algonquin Arch, extensively block faulted. There is no remaining evidence to prove

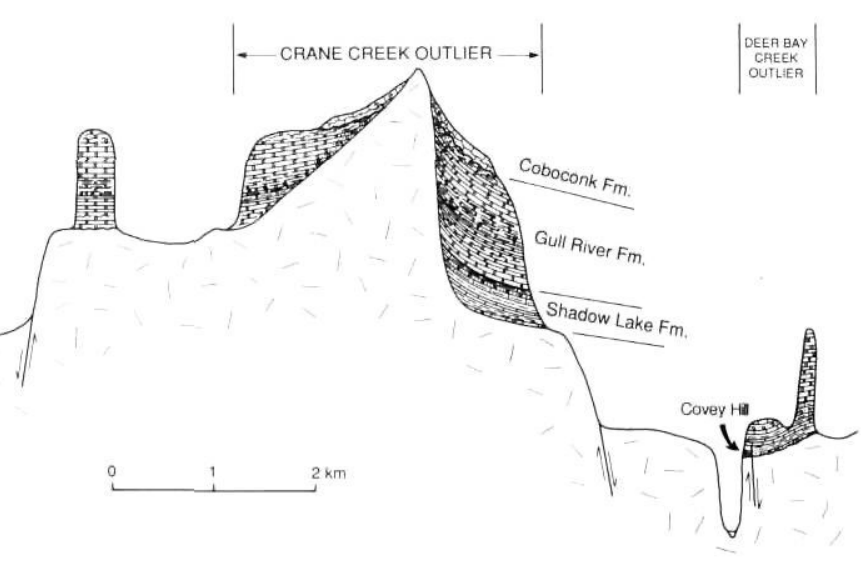

Coupe structurale B- $B^{\prime}$ (localisation à la fig. 2 et légende à la fig. 5B). 
m.a.s.l.

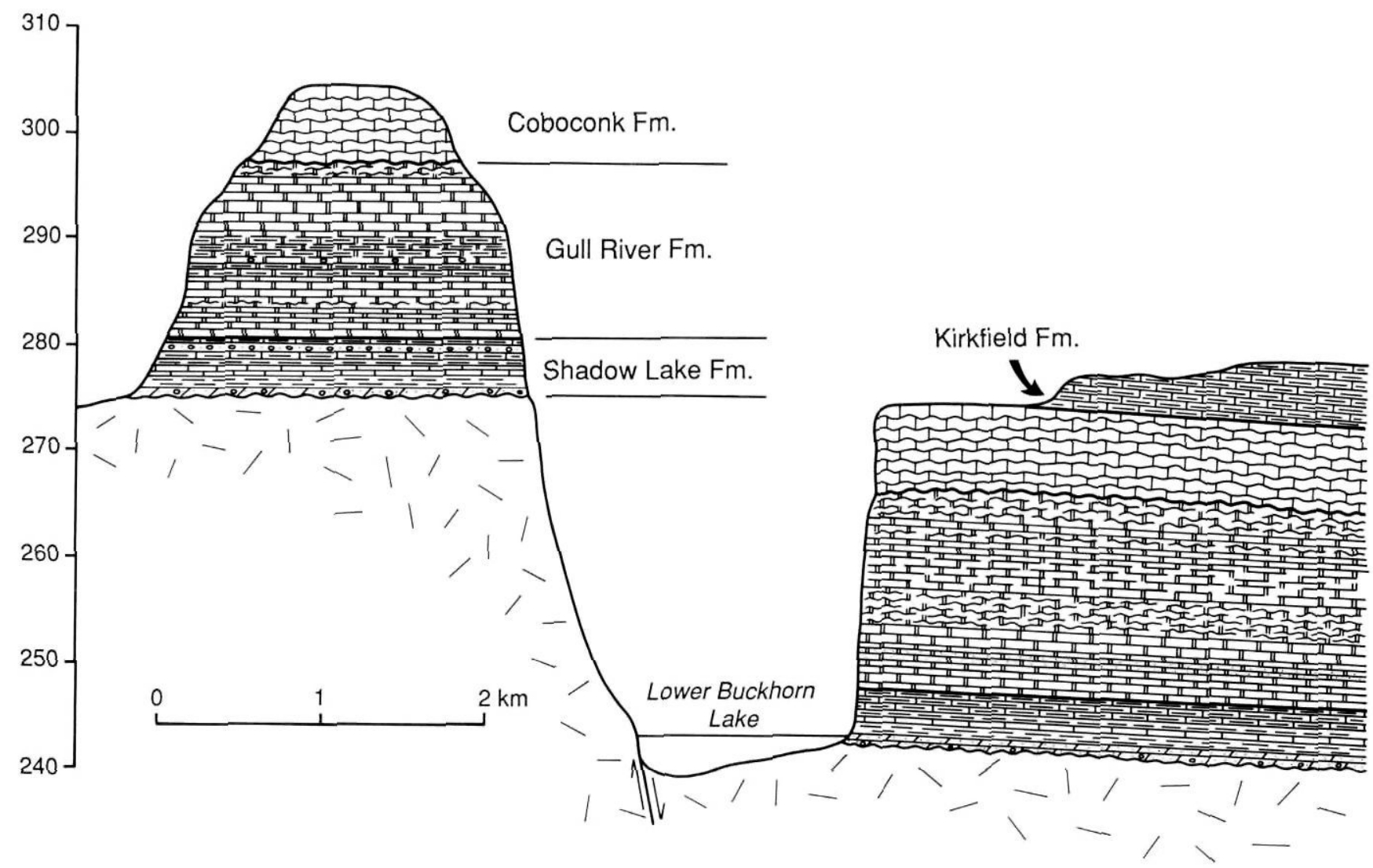

FIGURE 14. Structure section C-C' (see Fig. 2 for location and Fig. Coupe structurale C-C' (localisation à la fig. 2 et légende à la fig. 5B). $5 \mathrm{~B}$ for legend).

m.a.s.l.

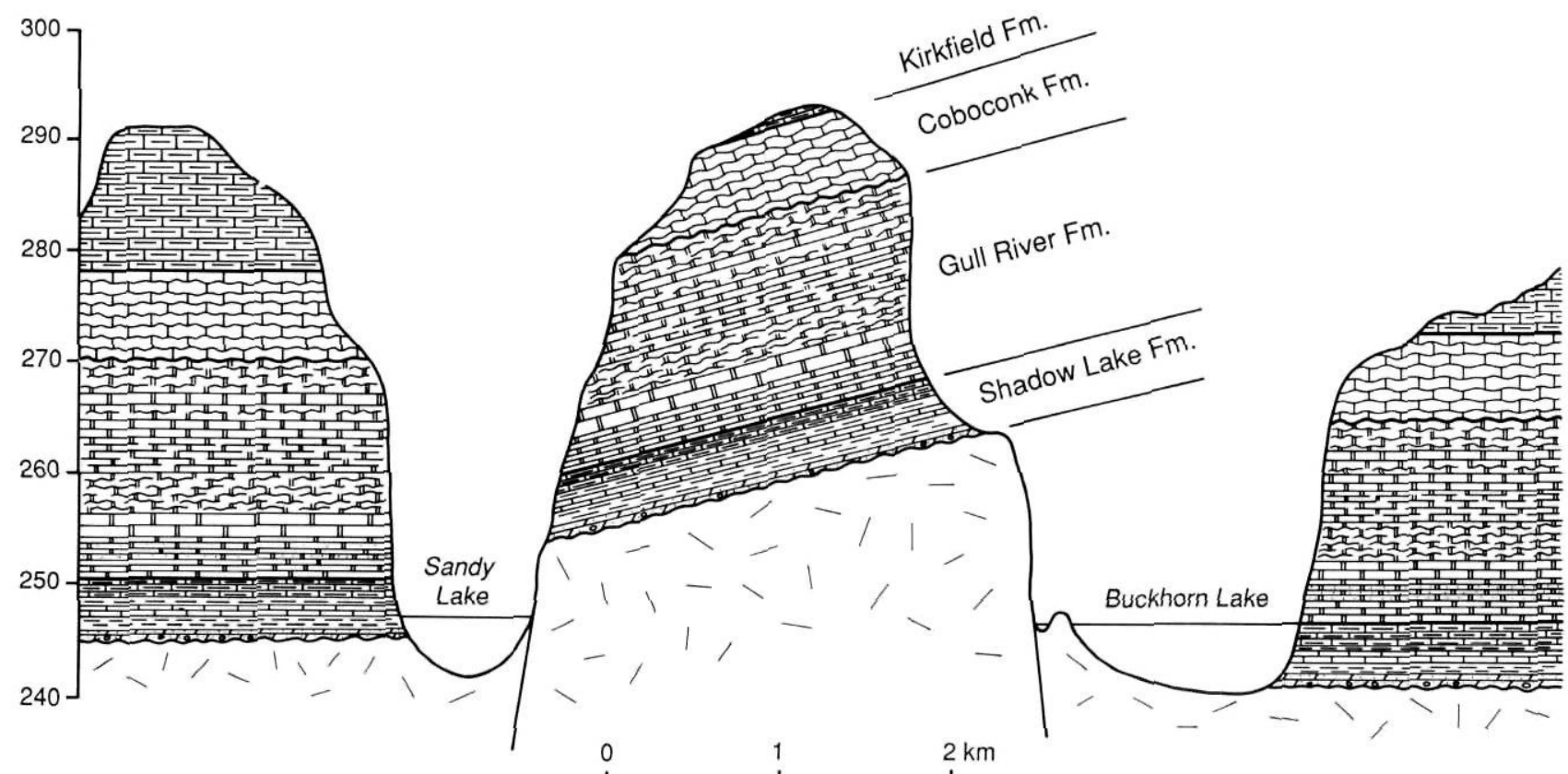

FIGURE 15. Structure section D-D' (see Fig. 2 for location and Fig. Coupe structurale D-D' (localisation à la fig. 2 et légende à la fig. 5B). $5 \mathrm{~B}$ for legend). 
whether or not the Head Lake-Burleigh Falls area was affected by this event, other than the local presence of possibly fault-bounded structures in Precambrian basement rocks that may have originated, in part, during this particular phase of epeirogeny.

The third event occurred during the early deposition of the Shadow Lake Formation and was documented at station 29 (Figs. 2, 6 and 13). In this exposure, the lower redbed shales are intersected, and vertically displaced, by a southwesttrending normal fault. Although the fault can be traced upward into the overlying carbonates and shales of the Shadow Lake, the rocks that have undergone vertical displacement are confined to the lowermost $0.55 \mathrm{~m}$ of the formation. A fourth period of movement is suggested by the presence of quartz-feldspar pebbles in limestone beds above the lowermost redbed unit of the Shadow Lake Formation at stations 28 and 29 (Figs. 2 and 13). The most likely source of the detritus would have been a nearby, newly uplifted segment of Precambrian terrain, presumably the Precambrian block underlying the Crane Creek outlier (Fig. 13). This block is believed to have been tectonically active at a number of points in time, and to have affected depositional processes from late Precambrian to post-late Middle Ordovician times.

The fifth period of possible crustal movement can be inferred from the facies changes that were recognized in Lower Gull River strata in the Burnt River and Head Lake areas. Evidence of similar structural movements affecting Gull River strata (fracturing and secondary dolomitization) have been found elsewhere in southwestern Ontario (Sanford, 1961, 1993b), suggesting that basement movements may have been widespread throughout the Great Lakes region of Canada and United States during this particular period of geological time.

The sixth and final period of basement uplift and block faulting covers a very long period of geological time extending from post-late Middle Ordovician to the present. The extent and effects of these tectonic movements are of major structural significance as illustrated in Figures 12 to 15 . From firsthand observations, and inferred information in the structure sections, major tectonism can be seen to have affected the Shadow Lake, Gull River and Coboconk formations in various parts of the Head Lake-Burleigh Falls area. What is not yet known is to what extent the same tectonics affected succeeding Ordovician strata in the map area, or perhaps even younger Paleozoic (Silurian and Devonian) rocks that were once present and have long since been removed by processes of subaerial erosion. The Great Lakes region of Canada and the United States have been affected by a number of epeirogenic events since the late Middle Ordovician, and any one or all of these could have contributed in some way to the deformation of the Ordovician sequence in south-central Ontario. The most widespread and intensive of these epeirogenies in central and south-eastern Canada was in the Silurian (late Llandovery to early Wenlock). Much of the faulting in the Ontario segment of the Michigan Basin and in the Hudson Bay Basin was coincident with that epeirogeny, suggesting that some of the deformation of Middle Ordovician rocks of the Head Lake-Burleigh Falls area may have been triggered by the same event.

\section{SUMMARY AND CONCLUSIONS}

Previous studies of the St. Lawrence Platform (Sanford et al., 1985; Sanford, 1993a) have established a close relationship between the epeirogenic movements of the eastern Canadian craton and the succession of plate tectonic and associated orogenic events in motion during various episodes of the Taconian, Acadian and Alleghanian orogenies. The major arch systems were the most affected by epeirogenic movements in the form of uplift, block faulting and subaerial erosion, particularly those elements that trend perpendicular to the continental margins and were eventually over-ridden by leading edges of advancing allochthons. One of these, very much applicable to the present study, is the Frontenac Arch and its southeastern extension, the Adirondack Uplift, that has continued to be a major positive tectonic element throughout Phanerozoic time. The Head Lake-Burleigh Falls area of south-central Ontario lies along the southwestern margin of the Frontenac Arch (Fig. 1) and was, thus, presumably on the "receiving end" of mild to intensive phases of epeirogeny for long intervals of Paleozoic and possible Mesozoic times. Some of the crustal movements have altered depositional processes in various segments of the map area and resulted in uplift, block faulting and the onset of subaerial erosion of some major significance. The sequence of such events as recorded or inferred in the Head Lake-Burleigh Falls area are briefly summarized as follows:

(i) Late Precambrian Hadrynian to early Early Cambrian block faulting and continental redbed (Covey Hill) deposition;

(ii) Early Middle Ordovician uplift of the Frontenac and Algonquin arches, and widespread erosion and removal of, and most remnants of upper Precambrian to lower Lower Cambrian redbeds as well as Cambrian and lower Ordovician sequences;

(iii) Late Middle Ordovician (first event), early Blackriveran Stage faulting and facies changes (lower Shadow Lake) due to differential basement movements;

(iv) Late Middle Ordovician (second event), early Blackriveran Stage probable block faulting and dispersal of quartz-feldspar conglomerate (upper Shadow Lake);

(v) Late Middle Ordovician (third event), middle Blackriveran Stage facies changes (lower Gull River) triggered by basement uplift; and

(vi) Post-late Middle Ordovician basement uplift and block faulting.

From a neotectonic perspective it would appear that the Frontenac Arch is still in an active state of rebound, as evidenced by the profusion of earthquake epicentres that coincide with its eastern margin from the Adirondack Mountains northwestward through eastern Ontario and western Québec. Thus far, earthquakes reported along the west side of the Frontenac Arch have been few and of low magnitude. The major contrast in neotectonic activity from one side of the arch to the other is not fully understood, but it may be related to the major changes in tectonic framework and resulting 
depositional and/or erosional processes that were newly established in late Early to early Middle Ordovician time. These Early Paleozoic movements resulted in deep subsidence and the longer term preservation of Upper Cambrian and Lower Ordovician rocks along the eastern flank of the Frontenac Arch beneath the Ottawa Embayment. In contrast, equivalent sequences on the western flank of the arch, and the adjacent Algonquin Arch, were substantially elevated and removed by processes of sub-aerial erosion. Perhaps one can conclude from this that the amount of structural rebound along the western margin of the Frontenac Arch, during the early Middle Ordovician, was of sufficient magnitude, such that substantially less movement has occurred in subsequent Phanerozoic times. If such is the case, then it might explain the current contrast between the apparently quiescent western margin of the Frontenac Arch and its tectonically active counterpart to the east.

\section{ACKNOWLEDGEMENTS}

An important component contributing to the structural interpretation contained herein, was the acquisition of precise elevations (above mean sea-level) on key stratigraphic horizons acquired in the field by William R. Coe Ltd., of Lindsay, Ontario. Their highly professional service saved the writer many hours of painstaking labour in the field, and added a precision to the results that otherwise could never have been achieved. A special thank you is also extended to Vernon Singhroy of the Canada Centre for Remote Sensing, Ottawa, for the temporary loan of a satellite radar image of a segment of south-central Ontario. The clarity of the image made it possible to identify certain of the lineaments (fractures) in the Head Lake/Burleigh Falls area (Fig. 5) not readily visible on conventional LANDSAT imagery.

The writer is most grateful to A.W. Norris, Geological Survey of Canada, Calgary, and Joe Wallach, Atomic Energy Control Board, Ottawa, for their critique of an early version of the manuscript, and their suggestions for improvement to the final contents of the paper. Finally the author thanks the Atomic Energy Control Board for having funded the study.

\section{REFERENCES}

Caley, J.F. and Liberty, B.A., 1952. Preliminary map of Fenelon Falls, Victoria, Peterborough, and Haliburton counties, Ontario (map and descriptive notes), Geological Survey of Canada. Paper 52-31, 1 inch to 1 mile scale.

Clark, T.H., 1967. Châteauguay Area, Châteauguay, Huntingdon, Beauharnois, Napierville and St. Jean counties. Québec Department of Natural Resources, Geological Report 122: 8-19

Douglas, R.J.W., 1969. Geological Map of Canada. Geological Survey of Canada, Map 1250A, scale 1:5,000,000

Energy, Mines and Resources, 1979. Burleigh Falls, Peterborough county, Ontario. Surveys and Mapping Branch, 31 D/9 Map sheet, Ed. 4, scale $1: 50,000$.

1980. Feneion Falls, Ontario. Surveys and Mapping Branch, 31 D/10 Map sheet, Ed. 4, scale 1:50,000.

Fisher, J.H. and Barrett, M.W., 1985. Exploration in Ordovician of central Michigan. American Association of Petroleum Geologists Bulletin, 69: 2065-2076.
Geological Survey of Canada, 1989. Aeromagnetic total field Lake Simcoe, Ontario. Geological Survey of Canada, Map 7053G, scale 1:250,000.

Hanmer, S., 1988. Ductile thrusting at mid-crustal level, southwestern Grenville Province. Canadian Journal of Earth Sciences, 25: 1049-1059.

Hofmann, H.J., 1972. Stratigraphy of the Montreal Area. International Geological Congress, Canada 1972, 24th Session Excursion B-03, 33 p.

Johnston, W.H., 1911. Simcoe district, Ontario. Geological Survey of Canada, Summary Report, p. 188-192.

Kay, G.M., 1942. Ottawa-Bonnechere Graben-Lake Ontario homocline. Geological Society of America Bulletin, 53: 585-646.

Liberty, B.A., 1955. Studies of the Ordovician System in central Ontario. Proceedings of the Geological Association of Canada, 7(1): 139-147.

- 1964. Middle Ordovician stratigraphy of the Lake Simcoe area, Ontario. American Association of Petroleum Geologists, and Society of Economic Paleontologists and Mineralogists, May 1964 Toronto, Canada Guidebook Geology of Central Ontario, p. 14-36.

- 1969. Paleozoic geology of the Lake Simcoe area, Ontario. Geological Survey of Canada, Memoir 355, 201 p.

McFall, G.H. and Allam, A., 1991. Neotectonic investigations in southcentral Ontario. Atomic Energy Control Board, Technical Report INFO 90-03, 97 p.

Okulitch, V.J., 1939. The Ordovician section at Coboconk, Ontario. Transactions of the Royal Canadian Institute, XXII (2): 319-339.

Sanford, B.V., 1961. Subsurface stratigraphy of Ordovician rocks in southwestern Ontario. Geological Survey of Canada, Paper 60-26, 54 p.

1993a. Geology of the St. Lawrence Platform; Chapter 11. In D.F. Stott and J.D. Aitken, ed. Sedimentary Cover of the Craton in Canada. Geological Survey of Canada, no. 5, 709-786.

1993b. In press. St. Lawrence Platform - Economic Geology; Chapter 12. In D.F. Stott and J.D. Aitken, ed. Sedimentary Cover of the Craton in Canada. Geological Survey of Canada, no. 5, 787-798.

Sanford, B.V. and Baer, A.J., 1981. Geological map of southern Ontario. Geological Survey of Canada, southern Ontario sheet 30S, 1335A, $1: 1,000,000$ scale.

Sanford, B.V. and Grant, A.C., 1990. New findings relating to the stratigraphy and structure of the Hudson Platform. In Current Research, Part D, Geological Survey of Canada, Paper 90-1D: 17-30.

Santord, B.V., Grant, A.C., Wade, J.A. and Barss, M.S., 1979. Geology of eastern Canada and adjacent areas. Geological Survey of Canada, Map 1401A (4 sheets), scale 1:2,000,000.

Sanford, B.V. and Quillian, R.G., 1959. Subsurface stratigraphy of Upper Cambrian rocks in southwestern Ontario. Geological Survey of Canada, Paper 58-12, $33 \mathrm{p}$.

Sanford, B.V., Thompson, F.J. and McFall, G.H., 1985. Plate tectonics - a possible controlling mechanism in the development of hydrocarbon traps in southwestern Ontario. Bulletin of Canadian Petroleum Geology, 33(1): 52-76.

Williams, D.A., Rae, A.M. and Wolf, R.R., 1984. Paleozoic geology of the Ottawa area, southern Ontario. Ontario Geological Survey, Map P.2716, Geological Series, Preliminary Map, scale 1:50,000.

Williams, D.A. and Wolf, R.R., 1982. Paleozoic geology of the northern part of the Ottawa - St. Lawrence Lowland, southern Ontario. Ontario Geological Survey, Miscellaneous Paper 106: 132-134.

Williams, Harold, 1979. Appalachian Orogen in Canada. Canadian Journal of Earth Sciences, 16: 792-807.

Wilson, J.T., 1966. Did the Atlantic close and then re-open? Nature, 211: 676-681.

Winder, C.G., 1954. Burleigh Falls and Peterborough map-areas, Ontario (report and two maps). Geological Survey of Canada, Paper 53-27, 1 inch to 1 mile scale.

Winder, C.G. and Sanford, B.V., 1972. Stratigraphy and paleontology of the Paleozoic rocks of southern Ontario. International Geological Congress, Canada 1972, 24th Session Field Excursion A45-C45, 74 . 